\title{
Effect of microbial inoculation and particle size on fermentation profile, aerobic stability, and ruminal in situ starch degradation of high-moisture corn ensiled for a short period
}

\author{
B. A. Saylor, F. Casale, (1) H. Sultana, and L. F. Ferraretto* (우 \\ Department of Animal Sciences, University of Florida, Gainesville 32611
}

\begin{abstract}
Dairy farmers are often challenged with the need to feed high-moisture corn (HMC) after less than $30 \mathrm{~d}$ of fermentation. The objective this study was to assess the effects of microbial inoculation and particle size on fermentation profile, aerobic stability, and ruminal in situ starch degradation of HMC ensiled for a short period. High-moisture corn was harvested, coarsely ground $(3,798 \pm 40 \mu \mathrm{m}$, on average $)$ or finely ground (984 $\pm 42 \mu \mathrm{m}$, on average), then ensiled in quadruplicate vacuum pouches untreated $(\mathrm{CON})$ or with the following treatments: Lactobacillus plantarum $\mathrm{CH} 6072$ at $5 \times 10^{4} \mathrm{cfu} / \mathrm{g}$ and Enterococcus faecium $\mathrm{CH} 212$ at $5 \times 10^{4} \mathrm{cfu} / \mathrm{g}$ of fresh forage (LPEF); or Lactobacillus buchneri LB1819 at $7.5 \times 10^{4} \mathrm{cfu} / \mathrm{g}$ and Lactococcus lactis $\mathrm{O} 224$ at $7.5 \times 10^{4} \mathrm{cfu} / \mathrm{g}(\mathrm{LBLL})$. Silos were allowed to ferment for 14 or $28 \mathrm{~d}$. Ruminal in situ starch degradation increased when HMC was finely ground. In addition, in situ starch degradation was greater and aerobic stability increased approximately 5-fold with LBLL compared with CON and LPEF. An interaction between microbial inoculation and storage length occurred for lactic acid. At $14 \mathrm{~d}$, concentrations of lactic acid were greatest in LPEF and lowest in LBLL. Lactic acid concentrations increased from 14 to $28 \mathrm{~d}$ with CON and LPEF, but decreased with LBLL. At $28 \mathrm{~d}$, concentrations of lactic acid were lower in LBLL compared with CON and LPEF. An interaction between particle size, microbial inoculation, and storage length occurred for acetic acid and ammonia-N. At 14 and $28 \mathrm{~d}$, acetic acid concentrations were greatest in finely ground LBLL followed by coarsely ground LBLL. Ammonia-N concentrations increased across all treatments from 0 to $28 \mathrm{~d}$. At 14 and $28 \mathrm{~d}$, concentrations of ammonia- $\mathrm{N}$ were greatest in finely ground LBLL and lowest in coarsely ground $\mathrm{CON}$ and coarsely ground LPEF. Results from this study suggest that L. buchneri
\end{abstract}

Received April 19, 2019.

Accepted August 31, 2019.

*Corresponding author: lferraretto@ufl.edu
LB1819 can produce acetic acid in as little as $14 \mathrm{~d}$, and that by $28 \mathrm{~d}$, it has the potential to improve the aerobic stability of HMC. Additionally, results indicate that $L$. buchneri LB1819 has the potential to improve ruminal degradation of starch by $28 \mathrm{~d}$ of storage. Finally, results confirm enhanced fermentation and improved ruminal starch degradation with finely ground HMC by $28 \mathrm{~d}$ of storage.

Key words: microbial inoculation, high-moisture corn, fermentation profile, ruminal starch degradation

\section{INTRODUCTION}

High-moisture corn (HMC) is a common feedstuff for ruminant animals, primarily due to its greater ruminal and total-tract starch digestibility compared with dry corn (Firkins et al., 2001; Ferraretto et al., 2013). During ensiling, the hydrophobic starch-protein matrix surrounding starch granules is broken down, making starch more accessible for microbial degradation in the rumen (Kotarski et al., 1992; McAllister et al., 1993). However, due to its low moisture content, achieving a thorough fermentation (measured by the accumulation of total acids produced) with HMC may be challenging (Kung et al., 2007). Organic acid production is often reduced in HMC because bacterial growth is inhibited due to limited water availability (Muck, 1988). Reduced organic acid production in HMC has been associated with reduced starch digestibility (Ferraretto et al., 2014), presumably because bacterial proteolysis in the silo is the primary mechanism associated with the breakdown of the protein matrix (Junges et al., 2017). Furthermore, Simpson (2001) reported that a low $\mathrm{pH}$ favors the activity of endosperm proteases in cereal grains, which may contribute to improvements in starch digestibility; endosperm proteases represent $30 \%$ of proteolysis occurring in the kernel during silo fermentation (Junges et al., 2017).

High-moisture corn is prone to aerobic deterioration because of its reduced fermentation capacity and high starch content compared with other ensiled feedstuffs, which can be used as a source of energy by 
yeasts (Kung et al., 2007). When HMC is exposed to air, yeasts begin to assimilate lactic acid (Kung et al., 2018). The subsequent rise in $\mathrm{pH}$ stimulates the growth of undesirable microorganisms, such as molds, resulting in spoilage and nutrient losses that negatively affect animal performance (Hoffman and Ocker, 1997). Several options are available for improving the fermentation of HMC, including the use of microbial inoculants. Homofermentative microbial inoculants, which contain bacteria that almost exclusively produce lactic acid, have been shown to reduce silage $\mathrm{pH}$ and improve DM recovery (Muck and Kung, 1997). Ferraretto et al. (2014) found that a reduction in $\mathrm{pH}$ was associated with a greater 7 -h ruminal in vitro starch digestibility in HMC. Therefore, homofermentative inoculants have the potential to improve starch digestibility in HMC through enhanced fermentation. Daniel et al. (2018) observed an increase in apparent total-tract neutral detergent solubles digestibility in cows fed corn silage treated with a homofermentative microbial inoculant. Alternatively, heterofermentative microbial inoculants, which contain bacteria capable of producing both lactic and acetic acid, have the potential to improve the aerobic stability of HMC. Lactobacillus buchneri, a heterolactic bacterium commonly included in silage microbial inoculants, has been reported to improve the aerobic stability of HMC (Taylor and Kung, 2002; Kung et al., 2007). Under anaerobic conditions, L. buchneri is capable of degrading moderate amounts of lactic into acetic acid, which has antifungal properties (Oude Elferink et al., 2001).

An alternative method by which to improve the fermentation of HMC involves increasing the length of the storage period. Ferraretto et al. (2014) reported a decrease in $\mathrm{HMC} \mathrm{pH}$ as storage length progressed. Increasing the length of storage has also been associated with greater starch digestibility. Prolonged ensiling $(>120 \mathrm{~d})$ facilitates the breakdown of the protein matrix surrounding starch granules (Hoffman et al., 2011), making the starch more available in the rumen. Unfortunately, prolonged ensiling is not always a possibility for farmers, and they are often challenged with the need to feed HMC after less than $30 \mathrm{~d}$ of fermentation. Furthermore, in an attempt to reduce labor, time, and energy costs, many farms prefer to feed whole or coarsely ground $\mathrm{HMC}$ rather than finely ground $\mathrm{HMC}$, and this may also compromise starch digestibility. Smaller particles maximize the surface area available for microbial attachment, which can improve the extent of proteolysis in the silo and starch hydrolysis in the rumen (Johnson et al., 2002). The overall effects of HMC particle size on fermentation, however, are unknown.

Methods to improve the fermentation capacity of coarsely ground HMC ensiled for less than $30 \mathrm{~d}$ war- rant further investigation. The objective of the present study was to assess the effects of microbial inoculation and particle size on the fermentation profile, aerobic stability, and ruminal in situ starch degradation of HMC ensiled for 14 or 28 d. We hypothesized that: (1) ensiling coarsely ground HMC would have negative effects on fermentation profile, aerobic stability, and ruminal in situ starch degradation; (2) microbial inoculation would improve organic acid production and starch digestibility; and (3) heterofermentative microbial inoculation would improve aerobic stability.

\section{MATERIALS AND METHODS}

Corn ears (5678VT2P, Croplan; WinField Solutions LLC, Shoreview, MN) were collected from 4 different locations in the same field at the University of Florida Plant Science Research and Education Unit (Citra, FL) in October of 2017, when kernel DM concentrations were approaching $70 \%$. Corn was shelled, homogenized manually, and coarsely ground using a large-scale wood chipper or finely ground using a tub grinder. One subsample of each particle size was collected, frozen, and used for nutrient characterization. Samples of coarsely and finely ground $\mathrm{HMC}(2.0 \pm 0.01 \mathrm{~kg}$ in size $)$ were assigned to 1 of 9 treatments. Treatments were a combination of 3 microbial inoculants and 3 storage lengths. Microbial inoculant treatments were as follows: distilled water, $0 \mathrm{cfu} / \mathrm{g}(\mathbf{C O N}) ; 5 \times 10^{4} \mathrm{cfu}$ of Lactobacillus plantarum $\mathrm{CH} 6072$ and $5 \times 10^{4}$ cfu of Enterococcus faecium CH212 per g of HMC (LPEF; Biomax SB; Chr. Hansen Animal Health and Nutrition, Milwaukee, WI); and $7.5 \times 10^{4}$ cfu of L. buchneri LB1819 and 7.5 $\times 10^{4}$ of Lactococcus lactis O224 per g of HMC (LBLL; SiloSolve FC; Chr. Hansen Animal Health and Nutrition). Inoculation rates were based on $\mathrm{cfu} / \mathrm{g}$ of wet material as recommended by the manufacturer. Before the experiment, bacterial populations were counted by pour plating on de Man, Rogosa, Sharpe agar (Oxoid, Basingstoke, UK). Bacterial counts were used to ensure that targeted inoculant application rates were met. Samples of HMC were individually treated with $50 \mathrm{~mL}$ of distilled water $(\mathrm{CON})$ or inoculant solution (LPEF or LBLL) before ensiling. Storage lengths were 0, 14, and 28 d. Each treatment combination had 4 replicates. All samples $(\mathrm{n}=72)$ were vacuum-sealed in nylon-polyethylene standard barrier vacuum pouches $(0.09 \mathrm{~mm}$ thick, $25.4 \times 35.6 \mathrm{~cm}$; Doug Care Equipment Inc., Springville, CA) using an external clamp vacuum machine (Bestvac; distributed by Doug Care Equipment). All mini-silos were filled and sealed within $3 \mathrm{~h}$ after harvest. Mini-silos with a designated storage length of $0 \mathrm{~d}$ were sealed after inoculant treatment and immediately frozen. All other mini-silos were weighed 
and stored at room temperature $\left(\sim 20^{\circ} \mathrm{C}\right)$ in the dark until reaching the targeted storage length.

After the designated length of storage, vacuum pouches were weighed (to determine fermentative DM losses) and opened. Fermentative DM losses were calculated as the difference between the weight of the HMC placed in each mini silo at ensiling and the weight of the HMC silage after the designated length of storage, corrected for the DM content of the fresh HMC and its respective silage. Approximately $300 \mathrm{~g}$ of each sample was immediately frozen at $-20^{\circ} \mathrm{C}$ to stop fermentation and stored until processed for analysis. Another $200 \mathrm{~g}$ of each sample was dried at $60^{\circ} \mathrm{C}$ for $48 \mathrm{~h}$ in a forced-air oven (Heratherm OMS180; Thermo Fisher Scientific, Waltham, MA) to determine the non-volatile DM concentration. Dried samples were then dry-sieved using a Tyler Ro-Tap Shaker (model RX-29; W.S. Tyler, Mentor, $\mathrm{OH}$ ) using a set of 9 sieves (W.S. Tyler) with nominal square apertures of 4.75, 3.35, 2.36, 1.70, 1.18, $0.60,0.30$, and $0.15 \mathrm{~mm}$ and pan (ASABE, 2007) to determine particle-size distribution. Geometric mean particle size $(\mu \mathrm{m})$ and surface area $\left(\mathrm{cm}^{2} / \mathrm{g}\right)$ were calculated using a $\log$ normal distribution (Baker and Herrman, 2002). Samples were then reconstituted and ground to pass through a $1-\mathrm{mm}$ screen in a Wiley mill (A. H. Thomas Scientific, Swedesboro, NJ). The remainder of each sample (approximately $1.5 \mathrm{~kg}$ ) was transferred to an open-top 3.78-L plastic bucket without packing for determination of aerobic stability. The buckets were covered with 2 layers of cheesecloth to prevent drying and placed on the floor of a room with a controlled environment. Two wireless sensors (HOBO temperature data logger 64 k; Onset Computer Corp., Cape Cod, MA) were placed in the geometrical center of the silage mass in each bucket, and temperatures were recorded at 30-min intervals for $10 \mathrm{~d}$. Three additional sensors monitored room temperature continuously. Room temperature averaged $21.3 \pm 0.6^{\circ} \mathrm{C}$ for the duration of the aerobic stability assay. Aerobic stability was defined as the time $(\mathrm{h})$ for the silage temperature to exceed $2.0^{\circ} \mathrm{C}$ above the ambient temperature. The difference between the silage temperature and the ambient temperature was calculated using the average temperature recorded every $30 \mathrm{~min}$ by the 2 sensors in the silage mass and 3 external sensors. In an attempt to more thoroughly characterize the process of aerobic deterioration, the following measurements were also collected: the mean silage temperature after $24 \mathrm{~h}$ of aerobic exposure; the maximum silage temperature after $10 \mathrm{~d}$ of aerobic exposure; the maximum difference between silage temperature and ambient temperature after $10 \mathrm{~d}$ of aerobic exposure; and the time to achieve the maximum difference between silage temperature and ambient temperature after $10 \mathrm{~d}$ of aerobic exposure. Measurements of DM loss and aerobic stability were performed on 14 and $28 \mathrm{~d}$ treatments only.

All dried and frozen samples were sent to Rock River Laboratory Inc. (Watertown, WI) for nutrient, fermentation profile, and ruminal in situ starch degradation analysis. Absolute DM was determined by oven-drying at $105^{\circ} \mathrm{C}$ for $3 \mathrm{~h}$ (method 2.2.2.5; NFTA, 1993). Unfermented samples were analyzed for DM, CP (method 990.03; AOAC International, 2012), ether extract (method 920.39; AOAC International, 2012), starch (Hall, 2015), water-soluble carbohydrates (WSC; Dubois et al., 1956), and ash (method 942.05, AOAC International, 2012). Neutral detergent fiber was determined using $\alpha$-amylase and sodium sulfite (aNDF; method 2002.04, AOAC International, 2012). Dried, fermented samples were analyzed for DM, CP, starch, borate-phosphate-soluble CP (Krishnamoorthy et al., 1982), and ruminal in situ starch degradation at $7 \mathrm{~h}$. For ruminal in situ starch degradation, approximately $3 \mathrm{~g}$ of dry, unground sample was weighed into filter bags $(\mathrm{R} 510,5 \times 10 \mathrm{~cm}, 50 \pm 10 \mu \mathrm{m}$ porosity; Ankom Technology, Macedon, NY) and incubated for $7 \mathrm{~h}$ in 3 cannulated lactating Holstein cows (1 bag per cow, yielding 3 analytical replicates) fed a diet consisting of $70 \%$ forage (a mixture of corn silage and alfalfa haylage) and $30 \%$ concentrate, on a DM basis.

Samples ensiled for 14 and 28 d were analyzed for organic acids. Twenty grams of undried, unground sample was diluted 10-fold (mass basis) in double-distilled water, blended for $30 \mathrm{~s}$ in a high-speed blender, and filtered through a filter funnel with a screen $(2-\mathrm{mm}$ pore size). The extract was collected and analyzed for $\mathrm{pH}$ using a $\mathrm{pH}$ meter (Thermo-Orion Dual Star; Thermo Fisher Scientific Inc.) fitted with a glass $\mathrm{pH}$ electrode (Thermo-Orion 9172BNWP; Thermo Fisher Scientific Inc.). After $\mathrm{pH}$ was measured, the extract was centrifuged $(750 \times g)$ for $20 \mathrm{~min}$ at $25^{\circ} \mathrm{C}$, and the supernatant was combined with $1.0 \mathrm{~mL}$ of calcium hydroxide solution and $0.5 \mathrm{~mL}$ of copper sulfate solution and re-centrifuged as described previously. The supernatant was analyzed for organic acids using HPLC with an isocratic pump, auto sampler, column heater, and refractive index detector $(1515,2707$, heater, and 2414 respectively; Waters Corporation, Milford, MA) and a reverse-phase ion exclusion column (Bio-Rad Aminex HPX-876H; Bio-Rad Laboratories, Hercules, CA). Flow rate and temperature were set at $0.6 \mathrm{~mL} / \mathrm{min}$ and $35^{\circ} \mathrm{C}$, respectively. The mobile phase used was $0.015 \mathrm{~N}$ $\mathrm{H}_{2} \mathrm{SO}_{4} / 0.25 \mathrm{~m} M$ EDTA.

For ammonia-N analysis, fresh sample (5 g) was diluted in $100 \mathrm{~mL}$ of distilled water and mixed for 30 min using a magnetic stir plate. Measurements were performed using a $\mathrm{pH} /$ ion selective electrode meter (Thermo-Orion 9172BNWP; Thermo Fisher Scientific 
Inc.) fitted with an ammonia-specific electrode (Orion High-Performance Ammonia Electrode; Thermo Fisher Scientific Inc.) equipped with a hydrophobic gaspermeable membrane. The membrane allows dissolved ammonia to diffuse across, separating ammonia-N from the rest of the solution. The probe was submerged into the solution, and $1 \mathrm{~mL}$ of $10 \mathrm{~N} \mathrm{NaOH}$ was added and ammonia- $\mathrm{N}$ was recorded.

Mold and yeast enumeration was performed on Petrifilm Rapid Yeast and Mold Count Plates (3M, Saint Paul, MN) using the technique described by Adesogan et al. (2004). Mold species identification was performed visually by trained technicians, who conducted a morphological examination of microscopic fungal structures as described in St. Germain and Summerbell (2010). Microbial data were log-transformed before statistical analysis.

Data were analyzed as a completely randomized design with a $2 \times 3 \times 3$ factorial arrangement of treatments using PROC GLIMMIX of SAS (SAS Institute Inc., Cary, NC). The model included particle size, microbial inoculation, storage length, and their interactions as fixed effects. Means were determined using the LSMEANS statement, and microbial inoculation treatment means were compared using the Bonferroni $t$ test option after a significant overall treatment $F$ test. Orthogonal contrasts were used to evaluate responses to storage length (14 vs. 28 d) and ensiling effects (0 d vs. 14 and $28 \mathrm{~d}$ ). Responses to ensiling ( $0 \mathrm{~d}$ vs. 14 and $28 \mathrm{~d}$ ) were evaluated only for nutrient, soluble CP, and ammonia- $\mathrm{N}$ concentrations, ruminal in situ starch degradation, yeast and mold counts, geometric mean particle size, and particle surface area data. Interaction effects were partitioned using the SLICE option to study the effect of microbial inoculation and particle size within each day of storage length. Organic acids, alcohols, pH, DM loss, and aerobic stability data were analyzed without $0 \mathrm{~d}$ as a completely randomized design with a $2 \times 3 \times 2$ factorial arrangement of treatments using the same model, with the exception that orthogonal contrasts to evaluate ensiling effects ( 0 d vs. 14 and 28 d) were not performed. Statistical significance and trends were declared at $P \leq 0.05$ and $P>0.05$ to $P \leq 0.10$, respectively. Main effects are presented and discussed only if the interaction effects were not significant $(P>0.05) ; P$-values for all 2 - and 3 -way interactions are presented in Table 1.

\section{RESULTS AND DISCUSSION}

The nutrient composition (DM basis) of unfermented HMC was as follows: $67.4 \% \mathrm{DM}$ (as fed), $9.6 \% \mathrm{CP}$, $4.2 \%$ ether extract, $10.4 \%$ aNDF, $66.4 \%$ starch, and $2.7 \%$ ash. These concentrations are within the range of those reported by Ferraretto et al. (2014), in which the nutrient composition of over 6,000 HMC samples was described. The geometric mean particle size $( \pm \mathrm{SD})$ of coarsely and finely ground HMC averaged 4,448 \pm $293 \mu \mathrm{m}$ and $985 \pm 128 \mu \mathrm{m}$, respectively. A detailed characterization of particle size for unfermented HMC can be found in Appendix Table A1.

We observed multiple 2-way interactions for $\mathrm{pH}(P$ $<0.05$; Figure 1). The interaction between particle size and microbial inoculation for $\mathrm{pH}$ is shown in Figure 1A $(P=0.001)$. When HMC was coarsely ground, $\mathrm{pH}$ was higher in LBLL than in CON and LPEF; in contrast, we observed no differences in $\mathrm{pH}$ among inoculant treatments for finely ground HMC. The interaction between microbial inoculation and storage length for $\mathrm{pH}$ is in Figure 1B $(P=0.001)$. At $14 \mathrm{~d}, \mathrm{pH}$ between inoculant treatments was not different. However, at $28 \mathrm{~d}$, the $\mathrm{pH}$ of LBLL was higher than CON and LPEF. Taylor and Kung (2002) and Kung et al. (2007) reported similar $\mathrm{pH}$ values in HMC treated with inoculants containing L. buchneri 40788.

The interaction between particle size and storage length for lactic acid is shown in Figure 2A $(P=0.002)$. At $14 \mathrm{~d}$, lactic acid concentrations were similar between coarsely and finely ground HMC. However, at $28 \mathrm{~d}$, lactic acid concentrations in the finely ground HMC were greater than those in the coarsely ground HMC. Increased moisture concentration and greater exposure of substrates to microbial fermentation may explain these differences in lactic acid concentration observed at 28 d. Reduced particle size increased lactic acid concentrations and decreased $\mathrm{pH}$ in a study conducted with rehydrated corn grain silage (C. L. S. Ávila, Universidade Federal de Lavras, Lavras, MG, Brazil, personal communication), supporting our premise. The interaction between microbial inoculation and storage length for lactic acid is shown in Figure 2B $(P=0.001)$. At 14 d, concentrations of lactic acid were greatest in LPEF and lowest in LBLL. Lactic acid concentrations increased from 14 to $28 \mathrm{~d}$ in CON and LPEF but decreased from 14 to $28 \mathrm{~d}$ for LBLL. At $28 \mathrm{~d}$, concentrations of lactic acid were lower in HMC treated with LBLL than in CON or LPEF.

We observed an interaction between particle size, microbial inoculation, and storage length for acetic acid, shown in Figure $3(P=0.001)$. At 14 and 28 d, acetic acid concentrations were highest in finely ground LBLL, followed by coarsely ground LBLL, then finely ground CON and finely ground LPEF, and lowest for coarsely ground CON and coarsely ground LPEF. The degradation of lactic acid to acetic acid by L. buchneri (Oude Elferink et al., 2001) is the most likely explanation for the relative concentrations of lactic and acetic acids in LBLL at $28 \mathrm{~d}$. This is in agreement with our study 
and perhaps explains the $\mathrm{pH}$ differences we observed, because acetic acid is weaker than lactic acid. Taylor and Kung (2002) and Kung et al. (2007) both reported an increase in $\mathrm{pH}$ when ground HMC was treated with L. buchneri 40788, which they attributed to a shift in fermentation from lactic toward acetic acid. Oude Elferink et al. (2001) reported that L. buchneri has a greater affinity for metabolizing lactic acid when the $\mathrm{pH}$ is close to 3.8. Our data, however, suggest that $L$. buchneri is capable of degrading significant amounts of lactic to acetic acid at a $\mathrm{pH}$ higher than has been previously reported. Similar findings have been reported in the literature (Taylor and Kung, 2002; Kung et al., 2007). Interestingly, Taylor and Kung (2002) reported that inoculation with L. buchneri 40788 had no effect on acetic acid concentrations in HMC ensiled for $14 \mathrm{~d}$ or less. After $49 \mathrm{~d}$ of fermentation, acetic acid concentrations were numerically greater in the treated HMC and statistically greater in treatments containing more than $6.6 \times 10^{5} \mathrm{cfu} / \mathrm{g}$ of L. buchneri 40788 (Taylor and Kung, 2002). However, our data showed greater acetic acid concentrations in HMC treated with L. buchneri
LB1819 by $14 \mathrm{~d}$. The discrepancy between studies could be due to the differences in L. buchneri strains, HMC DM, or the different storage methods used. Taylor and Kung (2002) ensiled HMC in polyvinyl chloride mini-silos sealed with rubber stoppers. With respect to the differences in acetic acid concentration between finely ground LBLL and coarsely ground LBLL, finely ground HMC possesses certain characteristics that could enhance the development of bacteria and thereby silage fermentation compared with HMC that is coarsely ground. These characteristics include greater moisture concentration and increased accessibility of kernel sugars to silage microbes due to the enhanced surface area (average of 33.3 vs. $11.6 \mathrm{~cm}^{2} / \mathrm{g}$, for finely and coarsely ground HMC, respectively). Butyric acid concentrations were unaffected $(P>0.10)$ by particle size, microbial inoculation, or storage length (Tables 2,3 , and 4 ). The presence of butyric acid in silage is generally indicative of clostridial fermentation. In the present study, however, concentrations of butyric acid were minimal (averaged $0.002 \%$ of DM) and of minor biological significance.

Table 1. Statistical analysis ( $P$-values) of the interaction effects of particle size (PS), microbial inoculation (I), and storage length (SL)

\begin{tabular}{|c|c|c|c|c|}
\hline \multirow[b]{2}{*}{ Item } & \multicolumn{4}{|c|}{ Interaction } \\
\hline & $\mathrm{PS} \times \mathrm{I}$ & $\mathrm{PS} \times \mathrm{SL}$ & $\mathrm{I} \times \mathrm{SL}$ & $\mathrm{PS} \times \mathrm{I} \times \mathrm{SL}$ \\
\hline \multicolumn{5}{|l|}{ Fermentation profile } \\
\hline $\mathrm{pH}$ & 0.001 & 0.58 & 0.001 & 0.52 \\
\hline Lactic acid, $\%$ of DM & 0.15 & 0.002 & 0.001 & 0.14 \\
\hline Acetic acid, $\%$ of DM & 0.001 & 0.001 & 0.001 & 0.001 \\
\hline Butyric acid, \% of DM & 0.38 & 0.32 & 0.38 & 0.38 \\
\hline Total acids, \% of DM & 0.001 & 0.001 & 0.18 & 0.33 \\
\hline Water-soluble carbohydrates, $\%$ of DM & 0.22 & 0.79 & 0.001 & 0.001 \\
\hline DM loss, $\%$ of DM & 0.005 & 0.10 & 0.10 & 0.36 \\
\hline Yeast count, log $\mathrm{cfu} / \mathrm{g}$ & 0.03 & 0.03 & 0.04 & 0.001 \\
\hline Mold count, $\log \mathrm{cfu} / \mathrm{g}$ & 0.48 & 0.17 & 0.08 & 0.69 \\
\hline Aerobic stability, $\mathrm{h}$ & 0.87 & 0.33 & 0.78 & 0.15 \\
\hline 24-h mean temperature, ${ }^{1}{ }^{\circ} \mathrm{C}$ & 0.08 & 0.10 & 0.002 & 0.90 \\
\hline $\mathrm{CP}, \%$ of $\mathrm{DM}$ & 0.04 & 0.91 & 0.34 & 0.37 \\
\hline Soluble CP, \% of CP & 0.47 & 0.18 & 0.62 & 0.96 \\
\hline Ammonia-N, \% of DM & 0.24 & 0.001 & 0.001 & 0.002 \\
\hline Ammonia-N, \% of $\mathrm{N}$ & 0.02 & 0.001 & 0.001 & 0.006 \\
\hline Starch, \% of DM & 0.07 & 0.35 & 0.006 & 0.04 \\
\hline Ruminal in situ starch degradation, ${ }^{5} \%$ of starch & 0.07 & 0.61 & 0.71 & 0.70 \\
\hline \multicolumn{5}{|l|}{ Particle size } \\
\hline Mean particle size, $\mu \mathrm{m}$ & 0.52 & 0.001 & 0.74 & 0.06 \\
\hline Surface area, $\mathrm{cm}^{2} / \mathrm{g}$ & 0.20 & 0.001 & 0.56 & 0.001 \\
\hline
\end{tabular}

\footnotetext{
${ }^{1}$ Mean silage temperature after $24 \mathrm{~h}$ of aerobic exposure.

${ }^{2}$ Maxium silage temperature after $10 \mathrm{~d}$ of aerobic exposure.

${ }^{3}$ Maximum difference between silage temperature and ambient temperature after $10 \mathrm{~d}$ of aerobic exposure.

${ }^{4}$ Time to reach the maximum difference between silage temperature and ambient temperature after $10 \mathrm{~d}$ of aerobic exposure.

${ }^{5}$ Ruminal in situ starch degradation at $7 \mathrm{~h}$ performed on dried and unground samples.
} 
We observed multiple 2-way interactions for concentrations of total acids (including lactic, acetic, butyric, propionic, succinic, and formic acids; Figure 4). The interaction between particle size and microbial inoculation for total acids is shown in Figure 4A $(P=0.001)$. Concentrations of total acids were greatest in finely ground LBLL, lowest in coarsely ground LBLL, and intermediate in the other treatment combinations. This may be an indication that inoculation with LBLL was more effective in finely ground HMC. The interaction between particle size and storage length for total acids is shown in Figure 4B $(P=0.001)$. At $14 \mathrm{~d}$, we found no difference in concentrations of total acids between
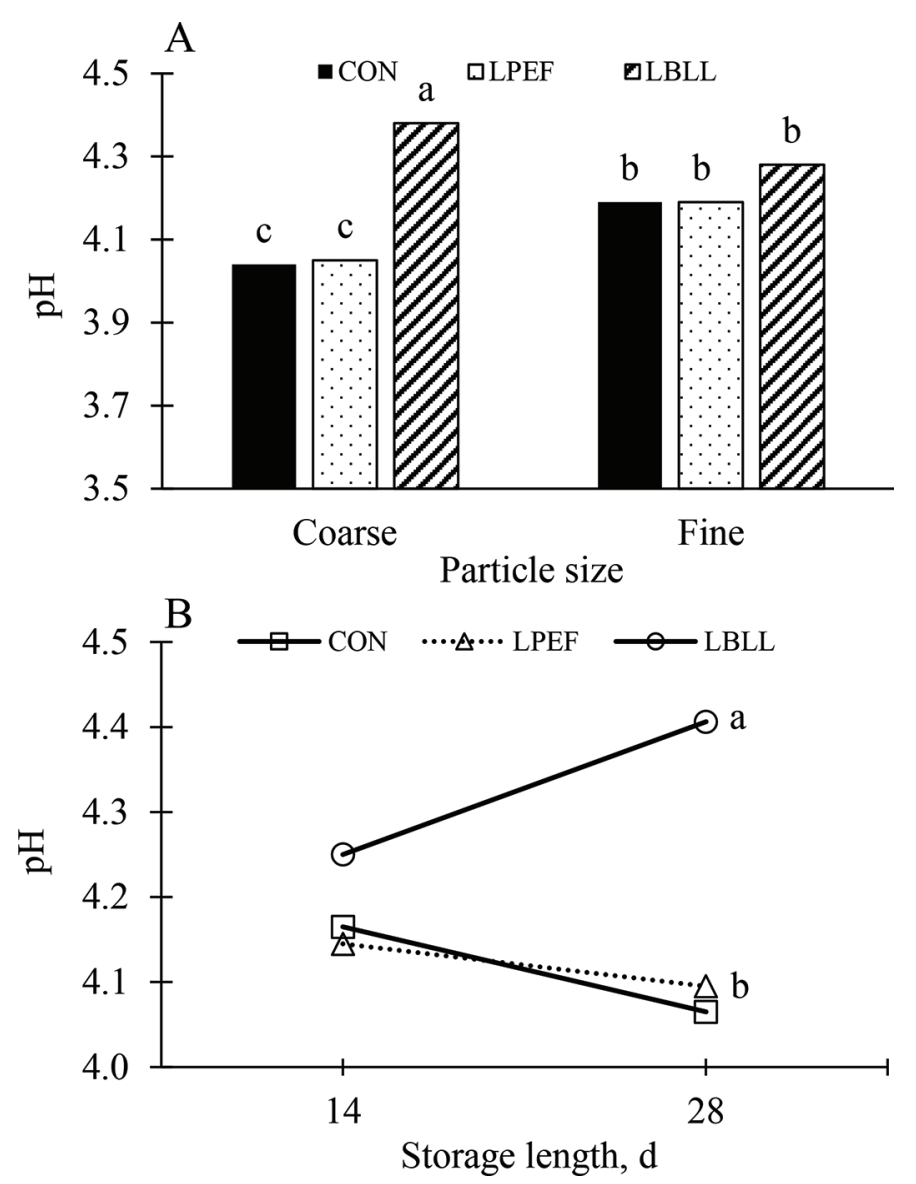

Figure 1. Effects of particle size and microbial inoculation (panel A; $P=0.001 ;$ SEM $=0.02$ ) and microbial inoculation and storage length (panel $\mathrm{B} ; P=0.001$; SEM $=0.02$ ) on $\mathrm{pH}$ of high-moisture corn. Corn was either coarsely or finely ground before storage. Inoculant treatments were distilled water (CON); Biomax SB (LPEF; Chr. Hansen Animal Health and Nutrition, Milwaukee, WI; application rate of $5 \times$ $10^{4} \mathrm{cfu} / \mathrm{g}$ of Lactobacillus plantarum CH6072 and Enterococcus faecium CH212); and SiloSolve FC (LBLL; Chr. Hanson Animal Health and Nutrition; application rate of $7.5 \times 10^{4} \mathrm{cfu} / \mathrm{g}$ of Lactobacillus buchneri LB1819 and Lactococcus lactis O224). Inoculation rates were based on $\mathrm{cfu} / \mathrm{g}$ of fresh forage. Panel A: means with different letters (a, b, c) differed $(P \leq 0.05)$; panel B: means within the same day with different letters $(\mathrm{a}, \mathrm{b})$ differed $(P \leq 0.05)$. coarsely and finely ground HMC. However, at $28 \mathrm{~d}$, total acids concentrations were greater in finely ground HMC than in coarsely ground HMC. As was mentioned previously, greater acid production in finely ground HMC is most likely related to the greater exposure of kernel sugars to microbial fermentation.

The interaction between particle size, microbial inoculation, and storage length for 1,2-propanediol is shown in Figure $5(P=0.001)$. At 14 and $28 \mathrm{~d}$, concentrations of 1,2-propanediol remained virtually undetectable in CON- and LPEF-treated samples. However, in HMC treated with LBLL, 1,2-propanediol was detected at 14 and $28 \mathrm{~d}$, and concentrations of 1,2-propanediol increased as storage length progressed. Additionally, 1,2-propanediol concentrations were greater in finely ground LBLL compared with coarsely ground LBLL
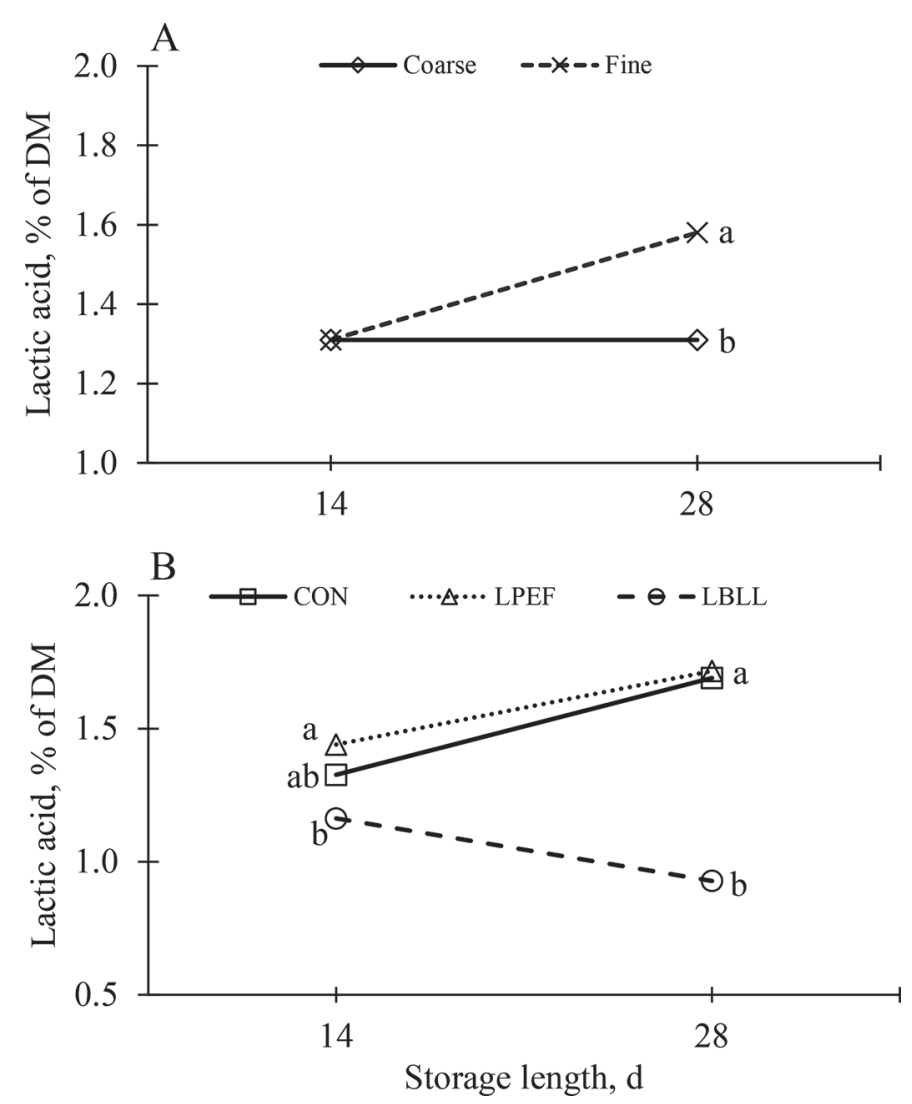

Figure 2. Effects of particle size and storage length (panel A; $P$ $=0.002 ; \mathrm{SEM}=0.04)$ and microbial inoculation and storage length (panel $\mathrm{B} ; P=0.001 ; \mathrm{SEM}=0.05$ ) on lactic acid concentration of high-moisture corn. Corn was either coarsely or finely ground before storage. Inoculant treatments were distilled water (CON); Biomax SB (LPEF; Chr. Hansen Animal Health and Nutrition, Milwaukee, WI; application rate of $5 \times 10^{4} \mathrm{cfu} / \mathrm{g}$ of Lactobacillus plantarum $\mathrm{CH} 6072$ and Enterococcus faecium CH212); and SiloSolve FC (LBLL; Chr. Hanson Animal Health and Nutrition; application rate of $7.5 \times 10^{4}$ cfu/g of Lactobacillus buchneri LB1819 and Lactococcus lactis O224). Panels A and B: means within the same day with different letters (a, b) differed $(P \leq 0.05)$. 
Table 2. Effects of particle size on fermentation profile and nutrient composition of high-moisture corn when averaged over inoculant treatment and storage length ${ }^{1}$

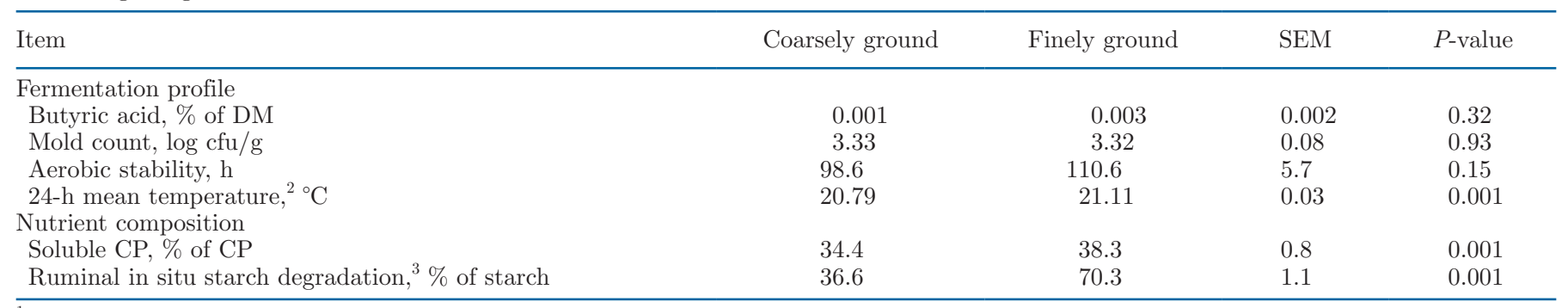

${ }^{1}$ Main effects are presented only if all 2- and 3-way interactions were nonsignificant $(P>0.05)$.

${ }^{2}$ Mean silage temperature from 0 to $24 \mathrm{~h}$ of aerobic exposure.

${ }^{3}$ Ruminal in situ starch degradation at $7 \mathrm{~h}$ performed on dried and unground samples.

at 14 and $28 \mathrm{~d}$. This finding was in agreement with the overall fermentation pattern observed in this study.

The 2-way interactions observed for ethanol concentrations are shown in Figure 6. The interaction between particle size and microbial inoculation for ethanol concentrations is shown in Figure $6 \mathrm{~A}(P=$ 0.002). Overall, ethanol concentrations were greater in coarsely ground HMC than in finely ground HMC. When HMC was coarsely ground, ethanol concentrations were greatest in HMC treated with LBLL and lowest in HMC treated with LPEF. When HMC was finely ground, ethanol concentrations were greater in HMC treated with LBLL than in the other 2 inoculant treatments. The interaction between particle size and storage length for ethanol concentrations is shown in Figure $6 \mathrm{~B}(P=0.001)$. At 14 and $28 \mathrm{~d}$ of storage, ethanol concentrations were greater in coarsely ground

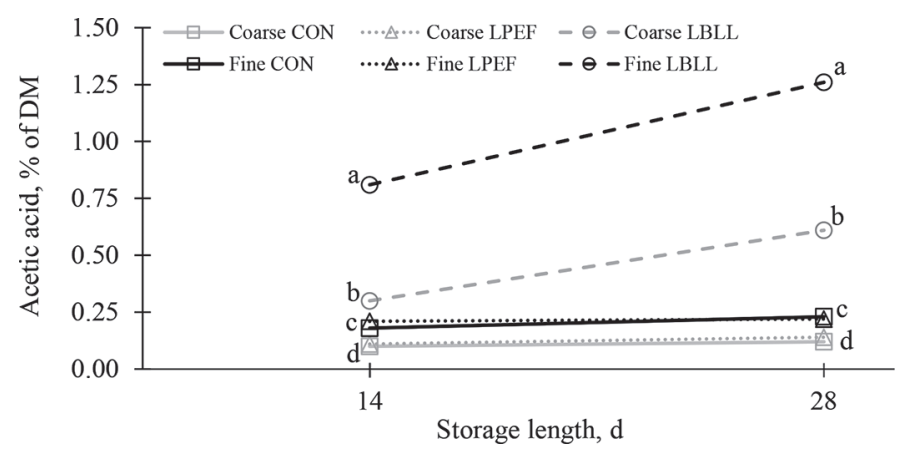

Figure 3. Effects of particle size, microbial inoculation, and storage length on acetic acid concentration of high-moisture corn. Corn was either coarsely or finely ground before storage. Inoculant treatments were distilled water (CON); Biomax SB (LPEF; Chr. Hansen Animal Health and Nutrition, Milwaukee, WI; application rate of $5 \times$ $10^{4} \mathrm{cfu} / \mathrm{g}$ of Lactobacillus plantarum $\mathrm{CH} 6072$ and Enterococcus faecium CH212); and SiloSolve FC (LBLL; Chr. Hanson Animal Health and Nutrition; application rate of $7.5 \times 10^{4} \mathrm{cfu} / \mathrm{g}$ of Lactobacillus buchneri LB1819 and Lactococcus lactis O224). Means within the same day with different letters $(\mathrm{a}-\mathrm{d})$ differed $(P \leq 0.05)$. Effects of particle size $(P=$ $0.001)$, microbial inoculation $(P=0.001)$, storage length $(P=0.001)$, and their interaction $(P=0.001) ; \mathrm{SEM}=0.01$.
HMC than in finely ground HMC. A shift from lactic acid toward acetic acid, 1,2-propanediol, and ethanol is commonly reported when silage is inoculated with $L$. buchneri, because it is capable of degrading lactic into these compounds (Oude Elferink et al., 2001).

We found no effect of storage length on DM loss $(P=$ 0.97). It is important to note, however, that this study investigated the effects of short-term ensiling, and that results could be different if fermentation were to persist beyond $28 \mathrm{~d}$. The interaction between particle size and microbial inoculation for DM loss is in Figure $7(P=0.005)$. Losses of DM were greater for finely ground LBLL than for finely ground LPEF and finely ground CON. Dry matter losses for finely ground CON were greater than those for coarsely ground LPEF, but not different from those for coarsely ground CON and coarsely ground LBLL. Fermentative DM losses in silage are primarily a result of carbon dioxide production (Borreani et al., 2018). Losses observed in this study fell within the range of those reported in the literature, where either corn grain or corn silage was fermented in laboratory-scale silos (Kleinschmit and Kung, 2006; Schmidt and Kung, 2010; Tabacco et al., 2011; da Silva et al., 2018). Greater DM losses with LBLL can most likely be attributed to the production of carbon dioxide when lactic acid is converted to acetic acid by $L$. buchneri LB1819 (Oude Elferink et al., 2001). Finely ground LBLL, in particular, would be expected to incur greater fermentative DM losses because of enhanced fermentation resulting from increased exposure of kernel sugars to microbial fermentation.

We observed an interaction between particle size, microbial inoculation, and storage length for yeast counts (Figure $8 ; P=0.001$ ). At $0 \mathrm{~d}$ we found no difference in yeast count among treatment combinations. At $14 \mathrm{~d}$, yeast counts were greatest in finely ground CON. At 28 $\mathrm{d}$, however, yeast counts were greater in finely ground LPEF than in the other treatment combinations. Yeast counts tend to decrease within the first few days of 
Table 3. Effects of microbial inoculation on fermentation profile, nutrient composition, and particle size of high-moisture corn when averaged over particle size and storage length ${ }^{1,2}$

\begin{tabular}{|c|c|c|c|c|c|}
\hline Item & $\mathrm{CON}$ & LPEF & LBLL & SEM & $P$-value \\
\hline \multicolumn{6}{|l|}{ Fermentation profile } \\
\hline Butyric acid, $\%$ of DM & 0.001 & 0.001 & 0.004 & 0.002 & 0.38 \\
\hline \multicolumn{6}{|l|}{ Nutrient composition } \\
\hline Soluble CP, \% of CP & $34.8^{\mathrm{b}}$ & $34.7^{\mathrm{b}}$ & $39.5^{\mathrm{a}}$ & 0.9 & 0.001 \\
\hline Ruminal in situ starch degradation, ${ }^{3} \%$ of starch & $50.8^{\mathrm{b}}$ & $52.2^{\mathrm{b}}$ & $57.5^{\mathrm{a}}$ & 1.3 & 0.002 \\
\hline
\end{tabular}

${ }_{\mathrm{a}, \mathrm{b}}$ Means with different superscript letters differed $(P \leq 0.05)$.

${ }^{1}$ Main effects are presented only if all 2- and 3-way interactions were nonsignificant $(P>0.05)$.

${ }^{2}$ Treatments were distilled water (CON); Biomax SB (LPEF; Chr. Hansen Animal Health and Nutrition, Milwaukee, WI; application rate of 5 $\times 10^{4} \mathrm{cfu} / \mathrm{g}$ of Lactobacillus plantarum CH6072 and Enterococcus faecium CH212); and SiloSolve FC (LBLL; Chr. Hanson Animal Health and Nutrition; application rate of $7.5 \times 10^{4} \mathrm{cfu} / \mathrm{g}$ of Lactobacillus buchneri LB1819 and Lactococcus lactis O224). Inoculation rates were based on $\mathrm{cfu} / \mathrm{g}$ of fresh forage.

${ }^{3}$ Ruminal in situ starch degradation at $7 \mathrm{~h}$ performed on dried and unground samples.

ensiling because of the rapid decline in $\mathrm{pH}$ and onset of anaerobiosis (Pahlow et al., 2003). Homofermentative inoculants such as LPEF may contribute to $\mathrm{pH}$ decline by producing large amounts of lactic acid in the early stages of fermentation. Heterofermentative inoculants are capable of producing acetic acid, which has antifungal properties (Oude Elferink et al., 2001). This could explain the lower yeasts counts we observed for inoculated samples compared with CON at $14 \mathrm{~d}$. However, the reason for greater yeasts counts in finely ground LPEF at $28 \mathrm{~d}$ is uncertain.

Mold counts were unaffected $(P>0.05)$ by HMC particle size (Table 2). The effects of microbial inoculation on mold counts are shown in Table 3. Mold counts were greatest in CON and lowest in LPEF. Microbial inoculation with LPEF likely reduced mold growth as a result of the rapid production of lactic acid and subsequent acidification. According to Muck (2010), low
$\mathrm{pH}$ and organic acids slow the growth of aerobic spoilage microorganisms. Effects of storage length on mold counts are in Table 4. The identity of detected molds present at d 0 can be found in Appendix Table A2. Mold counts were affected by ensiling $(P=0.001)$, but not by storage length $(P=0.98)$. The rapid acidification that occurs during the anaerobic phase of ensiling is most likely what inhibited mold growth in our study.

We found an effect of microbial inoculation on the aerobic stability of HMC. Aerobic stability was increased approximately 5-fold with LBLL compared with CON and LPEF ( $P=0.001$; Table 3$)$. This was likely related to greater acetic acid concentrations in LBLL compared with the other treatments (Figure 3). Yeasts are the primary cause of aerobic instability in most ensiled feeds. Acetic acid, which is produced by $L$. buchneri, has been shown to have antifungal properties (Oude Elferink et al., 2001) and to successfully inhibit

Table 4. Effects of storage length on fermentation profile and nutrient composition of high-moisture corn when averaged over particle size and inoculant treatment ${ }^{1}$

\begin{tabular}{|c|c|c|c|c|c|c|}
\hline Item & $0 \mathrm{~d}$ & $14 \mathrm{~d}$ & $28 \mathrm{~d}$ & SEM & \multicolumn{2}{|c|}{$P$-value ${ }^{2}$} \\
\hline \multicolumn{7}{|l|}{ Fermentation profile } \\
\hline Mold count, $\log \mathrm{cfu} / \mathrm{g}$ & 3.73 & 3.12 & 3.12 & 0.09 & 0.001 & 0.98 \\
\hline DM loss, $\%$ of DM & NA & 2.34 & 2.35 & 0.13 & NA & 0.97 \\
\hline Aerobic stability, h & NA & 101.2 & 108.0 & 5.7 & NA & 0.40 \\
\hline Ruminal in situ starch degradation, ${ }^{4} \%$ of starch & 39.3 & 57.2 & 64.0 & 1.3 & 0.001 & 0.001 \\
\hline
\end{tabular}

${ }^{1}$ Main effects are presented only if all 2- and 3-way interactions were insignificant $(P>0.05)$.

${ }^{2} \mathrm{E}=$ ensiling effect ( 0 vs. 14 and 28 d), SL = storage length effect (14 vs. 28 d).

${ }^{3}$ Not assessed.

${ }^{4}$ Ruminal in situ starch degradation at $7 \mathrm{~h}$ performed on dried and unground samples. 
yeasts in silage (Moon, 1983). Taylor and Kung (2002) and Kung et al. (2007) both reported improvements in aerobic stability when HMC was treated with $L$. buchneri 40788. The fact that we observed an improvement in aerobic stability with LBLL after $28 \mathrm{~d}$ of storage has profound implications for producers who may be forced to or prefer to open their silos after less than 30 d. Aerobic stability was unaffected by particle size and storage length $(P=0.15$ and $P=0.40$, respectively; Tables 2 and 4, respectively). Previously, the aerobic stability of corn silage was reported to be maximized at $120 \mathrm{~d}$ of fermentation (Daniel et al., 2015). Perhaps an increase in length of storage from 14 to $28 \mathrm{~d}$ is not
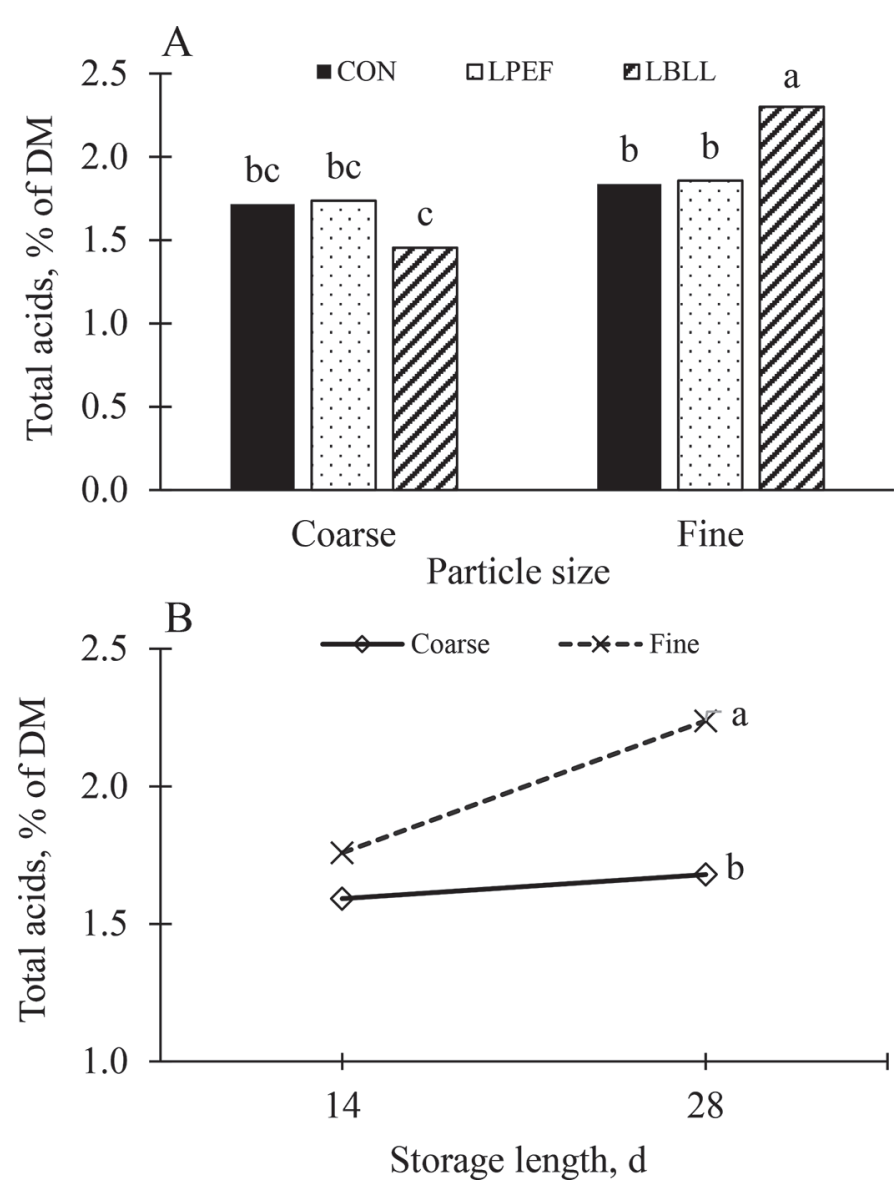

Figure 4. Effects of particle size and microbial inoculation (panel A; $P=0.001 ; \mathrm{SEM}=0.06$ ) and particle size and storage length (panel $\mathrm{B} ; P=0.001 ; \mathrm{SEM}=0.05)$ on total acid concentrations of high-moisture corn. Corn was either coarsely or finely ground before storage. Inoculant treatments were distilled water $(\mathrm{CON})$; Biomax SB (LPEF; Chr. Hansen Animal Health and Nutrition, Milwaukee, WI; application rate of $5 \times 10^{4} \mathrm{cfu} / \mathrm{g}$ of Lactobacillus plantarum $\mathrm{CH} 6072$ and Enterococcus faecium CH212); and SiloSolve FC (LBLL; Chr. Hanson Animal Health and Nutrition; application rate of $7.5 \times 10^{4} \mathrm{cfu} / \mathrm{g}$ of Lactobacillus buchneri LB1819 and Lactococcus lactis O224). Panel A: means with different letters $(\mathrm{a}-\mathrm{c})$ differed $(P \leq 0.05)$; panel B: means within the same day with different letters $(\mathrm{a}, \overline{\mathrm{b}})$ differed $(P \leq 0.05)$. sufficient to improve aerobic stability when LBLL is not applied.

The effect of microbial inoculation and storage length on mean silage temperature after $24 \mathrm{~h}$ of aerobic exposure is shown in Figure 9. After $14 \mathrm{~d}$ of ensiling, 24-h mean silage temperature was higher with LBLL than with CON. This temperature difference was minimal $\left(20.78\right.$ vs. $\left.20.50^{\circ} \mathrm{C}\right)$, however, and was most likely of minor biological significance. Across all inoculant treatments, mean silage temperature appeared to increase as storage length increased from 14 to $28 \mathrm{~d}$. After 28 $\mathrm{d}$ of ensiling, we found no difference in 24 -h mean silage temperature among the 3 inoculant treatments. The effect of particle size and microbial inoculation on maximum silage temperature after $10 \mathrm{~d}$ of aerobic exposure is shown in Figure 10A. The maximum silage temperature was greatest in finely ground $\mathrm{CON}$ and finely ground LPEF, intermediate in coarsely ground CON and coarsely ground LPEF, and lowest in coarsely ground and finely ground LBLL. The effect of microbial inoculation and storage length on maximum silage temperature after $10 \mathrm{~d}$ of aerobic exposure is shown in Figure 10B. After 14 and $28 \mathrm{~d}$ of storage followed by $10 \mathrm{~d}$ of aerobic exposure, maximum silage temperature was higher in CON and LPEF than in LBLL. Very few studies have characterized the effect of microbial inoculation on temperature changes in HMC following a period of aerobic exposure. Oxygen infiltration into the silage mass has been shown to stimulate the growth of lactate-assimilating yeasts and increase silage tem-

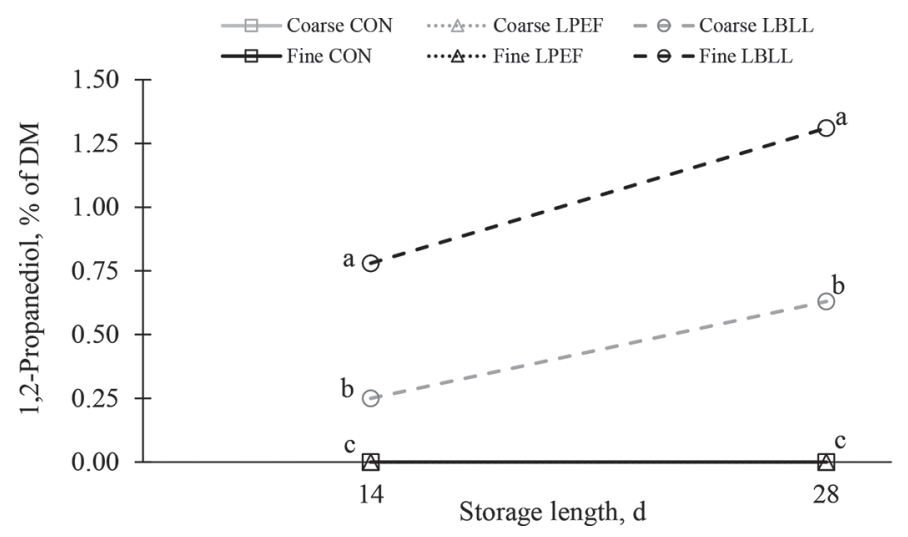

Figure 5. Effects of particle size, microbial inoculation, and storage length on 1,2-propanediol concentrations of high-moisture corn. Corn was either coarsely or finely ground before storage. Inoculant treatments were distilled water (CON); Biomax SB (LPEF; Chr. Hansen Animal Health and Nutrition, Milwaukee, WI; application rate of 5 $\times 10^{4}$ of Lactobacillus plantarum $\mathrm{CH} 6072$ and Enterococcus faecium CH212); and SiloSolve FC (LBLL; Chr. Hanson Animal Health and Nutrition; application rate of $7.5 \times 10^{4} \mathrm{cfu} / \mathrm{g}$ of Lactobacillus buchneri LB1819 and Lactococcus lactis O224). Means within the same day with different letters $(\mathrm{a}-\mathrm{c})$ differed $(P \leq 0.05)$. Effects of particle size $(P=$ $0.001)$, microbial inoculation $(P=0.001)$, storage length $(P=0.001)$, and their interaction $(P=0.001) ;$ SEM $=0.01$. 
perature (Kung et al., 2018). The subsequent rise in $\mathrm{pH}$ can result in the growth of molds and other detrimental microorganisms, which can lead to additional heating. Driehuis et al. (1999) observed that inoculation of corn silage with $L$. buchneri PW01 reduced the survival of yeasts during the anaerobic storage phase and inhibited the growth of yeasts when the silage was exposed to oxygen. These results can likely be attributed to the degradation of lactic into acetic acid by L. buchneri, which reduces the amount of lactic acid available for yeast growth while simultaneously producing acetic acid, which is known to have antifungal properties. The concentrations of lactic and acetic acids observed in our study, in combination with reduced silage heating with
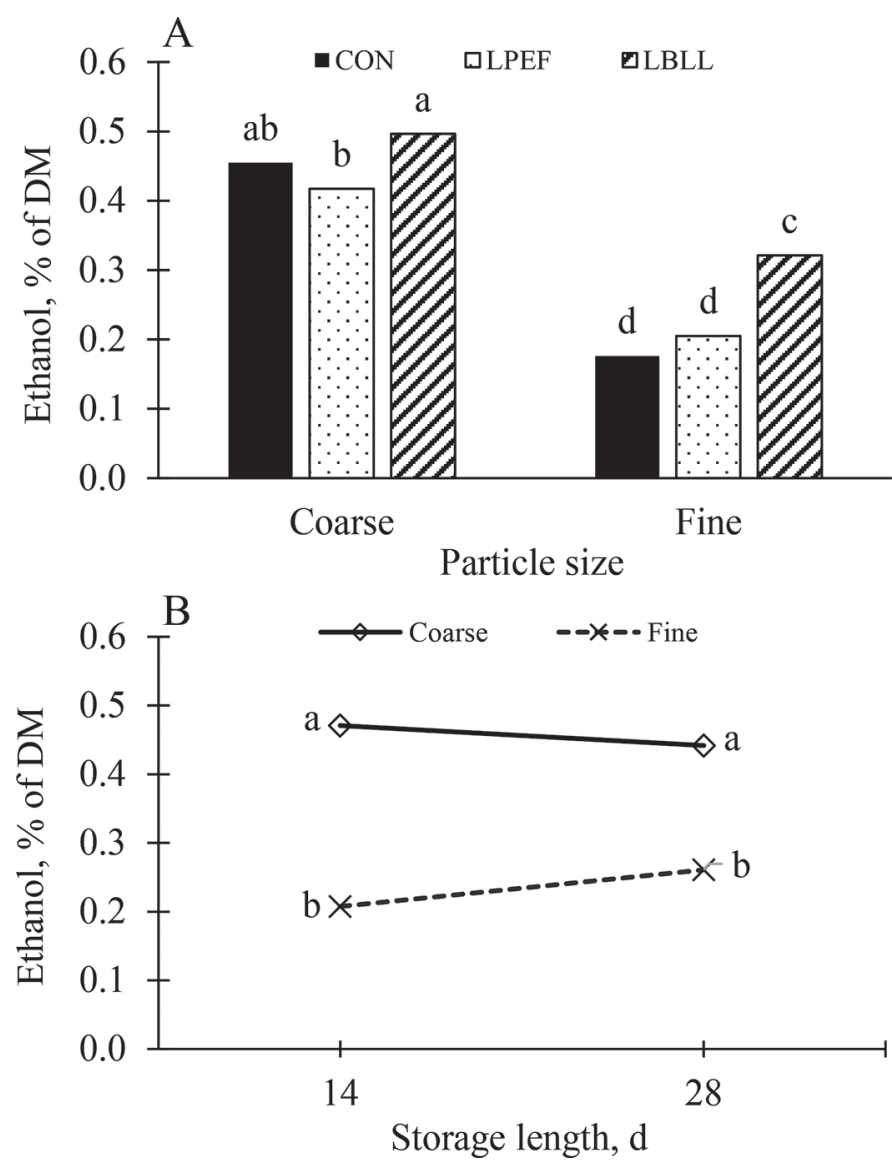

Figure 6. Effects of particle size and microbial inoculation (panel $\mathrm{A} ; P=0.002 ; \mathrm{SEM}=0.01$ ) and particle size and storage length (panel $\mathrm{B} ; P=0.001 ; \mathrm{SEM}=0.01)$ on ethanol concentrations of high-moisture corn. Corn was either coarsely or finely ground before storage. Inoculant treatments were distilled water $(\mathrm{CON})$; Biomax SB (LPEF; Chr. Hansen Animal Health and Nutrition, Milwaukee, WI; application rate of $5 \times 10^{4} \mathrm{cfu} / \mathrm{g}$ of Lactobacillus plantarum $\mathrm{CH} 6072$ and Enterococcus faecium CH212); and SiloSolve FC (LBLL; Chr. Hanson Animal Health and Nutrition; application rate of $7.5 \times 10^{4} \mathrm{cfu} / \mathrm{g}$ of Lactobacillus buchneri LB1819 and Lactococcus lactis O224). Panel A: means with different letters $(\mathrm{a}-\mathrm{d})$ differed $(P \leq 0.05)$; panel B: means within the same day with different letters $(\mathrm{a}, \overline{\mathrm{b}})$ differed $(P \leq 0.05)$.

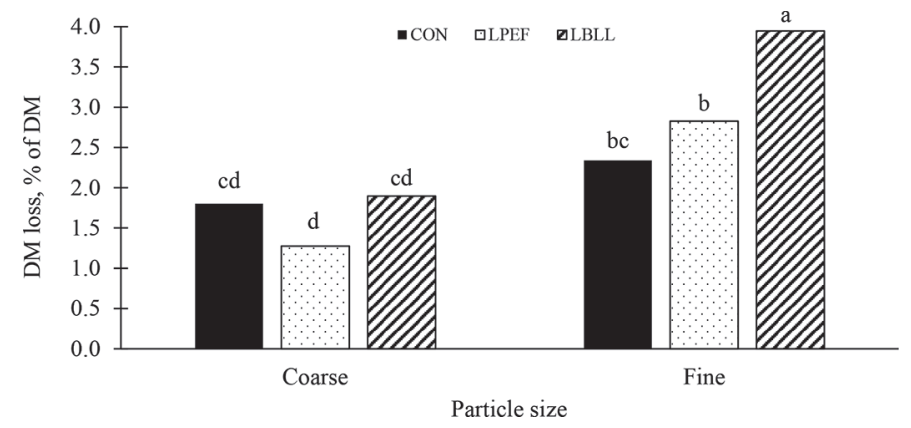

Figure 7. Effect of particle size and microbial inoculation $(P=$ 0.005 ; SEM $=0.04)$ on DM loss of high-moisture corn. Corn was either coarsely or finely ground before storage. Inoculant treatments were distilled water (CON); Biomax SB (LPEF; Chr. Hansen Animal Health and Nutrition, Milwaukee, WI; application rate of $5 \times 10^{4}$ cfu/g of Lactobacillus plantarum $\mathrm{CH} 6072$ and Enterococcus faecium CH212); and SiloSolve FC (LBLL; Chr. Hanson Animal Health and Nutrition; application rate of $7.5 \times 10^{4} \mathrm{cfu} / \mathrm{g}$ of Lactobacillus buchneri LB1819 and Lactococcus lactis O224). Means with different letters $(\mathrm{a}-\mathrm{d})$ differed $(P \leq 0.05)$.

LBLL following a period of aerobic exposure after silo opening, support this hypothesis.

The effect of particle size and microbial inoculation on the maximum difference between silage temperature and ambient temperature after $10 \mathrm{~d}$ of aerobic exposure is shown in Figure 11A. The maximum difference between silage temperature and ambient temperature was greatest in finely ground $\mathrm{CON}$ and finely ground LPEF, intermediate in coarsely ground $\mathrm{CON}$ and coarsely ground LPEF, and lowest in coarsely ground and finely

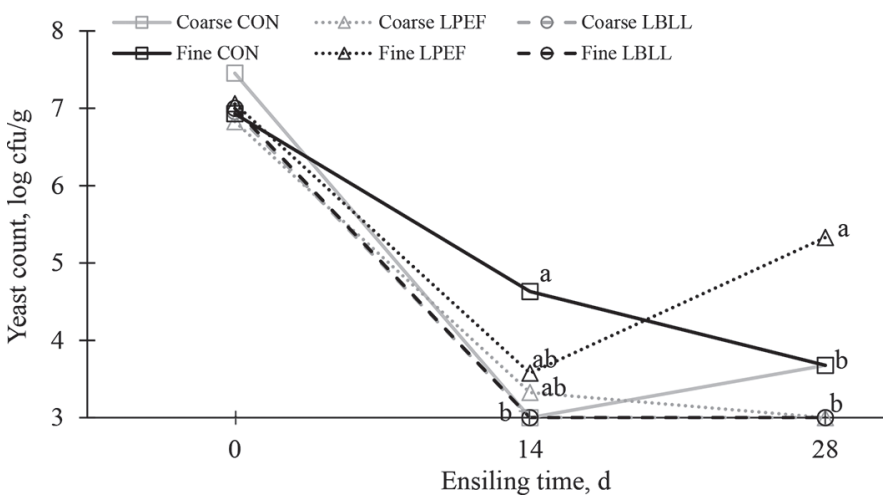

Figure 8. Effects of particle size, microbial inoculation, and storage length on yeast counts in high-moisture corn. Corn was either coarsely or finely ground before storage. Inoculant treatments were distilled water (CON); Biomax SB (LPEF; Chr. Hansen Animal Health and Nutrition, Milwaukee, WI; application rate of $5 \times 10^{4}$ cfu/g of Lactobacillus plantarum $\mathrm{CH} 6072$ and Enterococcus faecium CH212); and SiloSolve FC (LBLL; Chr. Hanson Animal Health and Nutrition; application rate of $7.5 \times 10^{4} \mathrm{cfu} / \mathrm{g}$ of Lactobacillus buchneri LB1819 and Lactococcus lactis O224). Means within the same day with different letters $(\mathrm{a}, \mathrm{b})$ differed $(P \leq 0.05)$. Effects of particle size $(P=$ $0.002)$, microbial inoculation $(P=0.002)$, storage length $(P=0.001)$, and their interaction $(P=0.001)$ were significant; $\mathrm{SEM}=0.29$. 
ground LBLL. The effect of microbial inoculation and storage length on the maximum difference between silage temperature and ambient temperature after 10 $\mathrm{d}$ of aerobic exposure is shown in Figure 11B. As storage length increased from 14 to $28 \mathrm{~d}$, the maximum difference between silage temperature and ambient temperature after $10 \mathrm{~d}$ of aerobic exposure gradually increased for CON and LPEF but decreased for LBLL. Furthermore, the maximum difference between silage temperature and ambient temperature was greater for CON and LPEF than for LBLL after 14 and $28 \mathrm{~d}$ of storage. These findings can likely be attributed to elevated concentrations of lactic acid with CON and LPEF, and reduced lactic and elevated acetic acid concentrations with LBLL after $28 \mathrm{~d}$ of storage compared with $14 \mathrm{~d}$. The effect of particle size, microbial inoculation, and storage length on the time to reach the maximum difference between silage temperature and ambient temperature after $10 \mathrm{~d}$ of aerobic exposure is shown in Figure 12. The time to reach the maximum difference between silage temperature and ambient temperature was reduced with finely ground LBLL compared with the other treatment combinations in HMC stored for both 14 and $28 \mathrm{~d}$. Although the maximum difference between silage temperature and ambient temperature was reached after a shorter period of time with LBLL, the maximum silage temperature and maximum difference between silage temperature and ambient temperature was reduced with LBLL. These findings are novel and warrant further investigation.

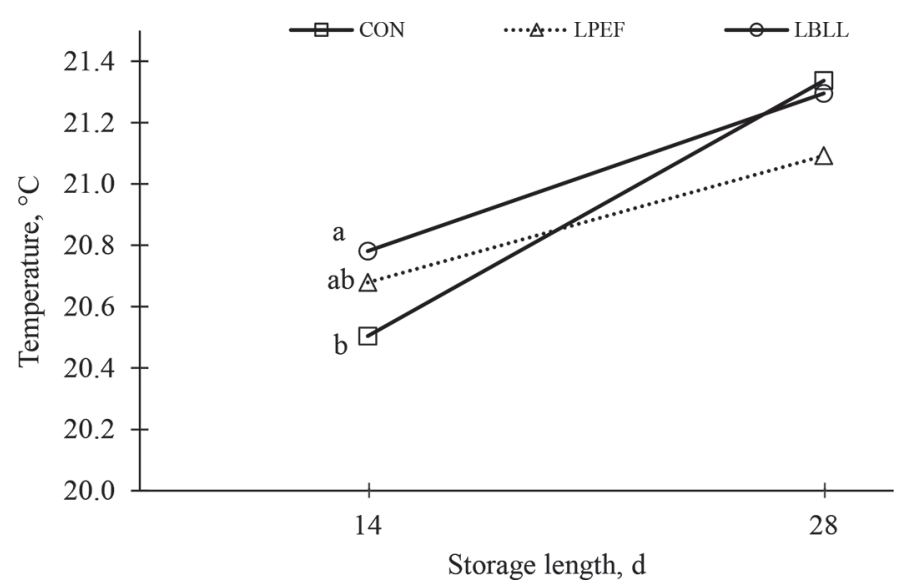

Figure 9. Effect of microbial inoculation and storage length on mean silage temperature after $24 \mathrm{~h}$ of aerobic exposure $(P=0.002$; $\mathrm{SEM}=0.06)$. Inoculant treatments were distilled water $(\mathrm{CON})$; Biomax SB (LPEF; Chr. Hansen Animal Health and Nutrition, Milwaukee, WI; application rate of $5 \times 10^{4} \mathrm{cfu} / \mathrm{g}$ of Lactobacillus plantarum CH6072 and Enterococcus faecium CH212); and SiloSolve FC (LBLL; Chr. Hanson Animal Health and Nutrition; application rate of $7.5 \times 10^{4} \mathrm{cfu} / \mathrm{g}$ of Lactobacillus buchneri LB1819 and Lactococcus lactis $\mathrm{O} 224)$. Means within the same day with different letters $(\mathrm{a}, \mathrm{b})$ differed $(P \leq 0.05)$.
The interaction between particle size and microbial inoculation for DM concentrations is shown in Figure $13(P=0.02)$. With the exception of finely ground CON, DM concentrations were greater in coarsely ground HMC than in finely ground HMC. Reduced DM concentrations in finely ground HMC might be partially related to the method used to quantify the DM content. Heat during oven-drying volatilizes alcohols, acetate, propionate, and a portion of the lactate (Woolford, 1984). If these compounds were to volatilize during the drying process, the measured DM concentration of finely ground HMC would be lower than
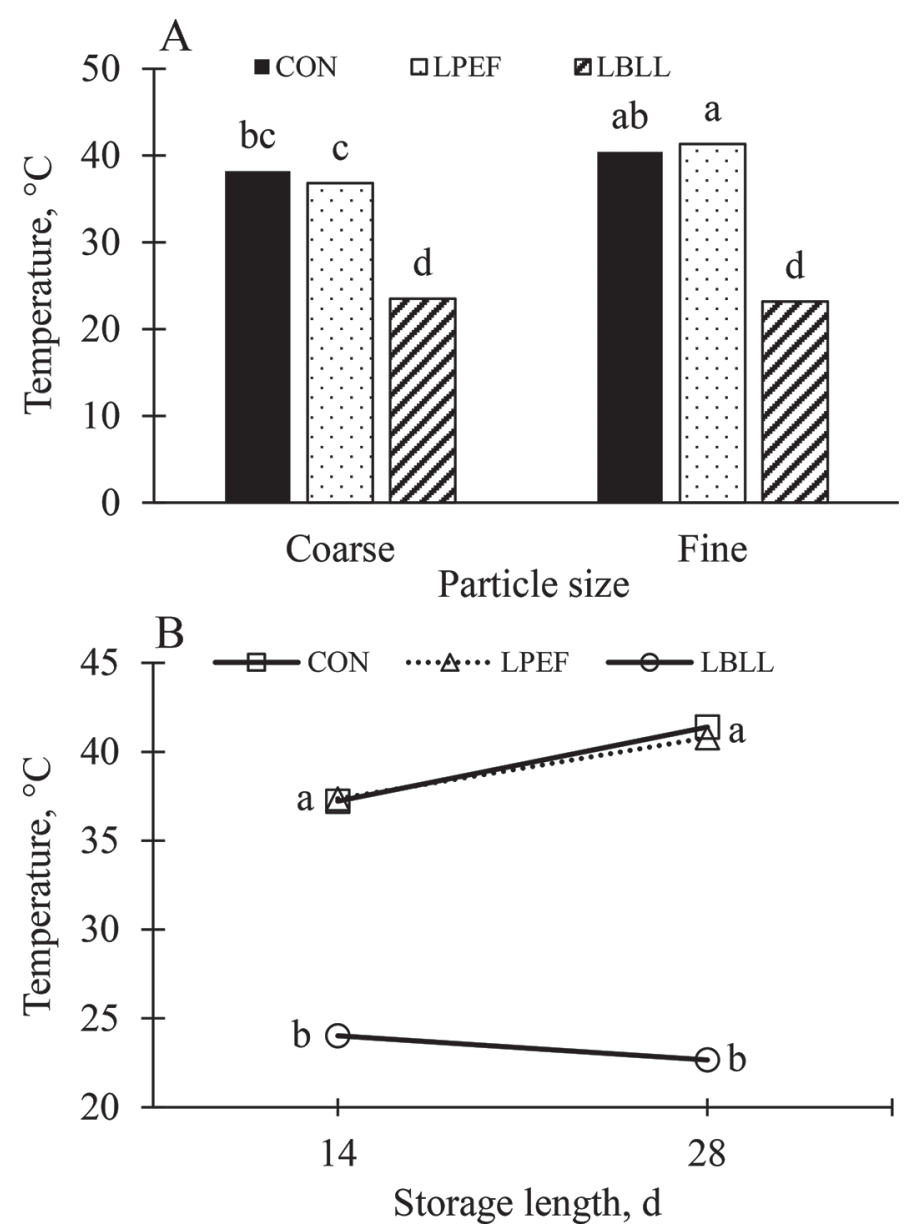

Figure 10. Effects of particle size and microbial inoculation (panel $\mathrm{A} ; P=0.001 ; \mathrm{SEM}=0.54)$ and microbial inoculation and storage length (panel $\mathrm{B} ; P=0.001$; $\mathrm{SEM}=0.50$ ) on maximum silage temperature after $10 \mathrm{~d}$ of aerobic exposure. Corn was either coarsely or finely ground before storage. Inoculant treatments were distilled water (CON); Biomax SB (LPEF; Chr. Hansen Animal Health and Nutrition, Milwaukee, WI; application rate of $5 \times 10^{4} \mathrm{cfu} / \mathrm{g}$ of Lactobacillus plantarum CH6072 and Enterococcus faecium CH212); and SiloSolve FC (LBLL; Chr. Hanson Animal Health and Nutrition; application rate of $7.5 \times 10^{4} \mathrm{cfu} / \mathrm{g}$ of Lactobacillus buchneri LB1819 and Lactococcus lactis O224). Panel A: means with different letters $(\mathrm{a}-\mathrm{d})$ differed $(P$ $\leq 0.05$ ); panel B: means within the same day with different letters (a, b) differed $(P \leq 0.05)$. 
that of coarsely ground HMC, because finely ground HMC contained greater concentrations of these volatile compounds than coarsely ground HMC. This is also in agreement with our DM loss data (Figure 7).

We observed an interaction between particle size, microbial inoculation, and storage length for WSC and starch $(P<0.05$; Figures $14 \mathrm{~A}$ and $14 \mathrm{~B}$, respectively). At $0 \mathrm{~d}$, concentrations of WSC were greater in finely ground LBLL than in finely ground LPEF and coarsely ground CON. At $14 \mathrm{~d}$, we found no difference in WSC concentrations among treatments. At $28 \mathrm{~d}$, WSC concentrations were greatest in finely ground LPEF and lowest in finely ground LBLL. As fermentation pro-
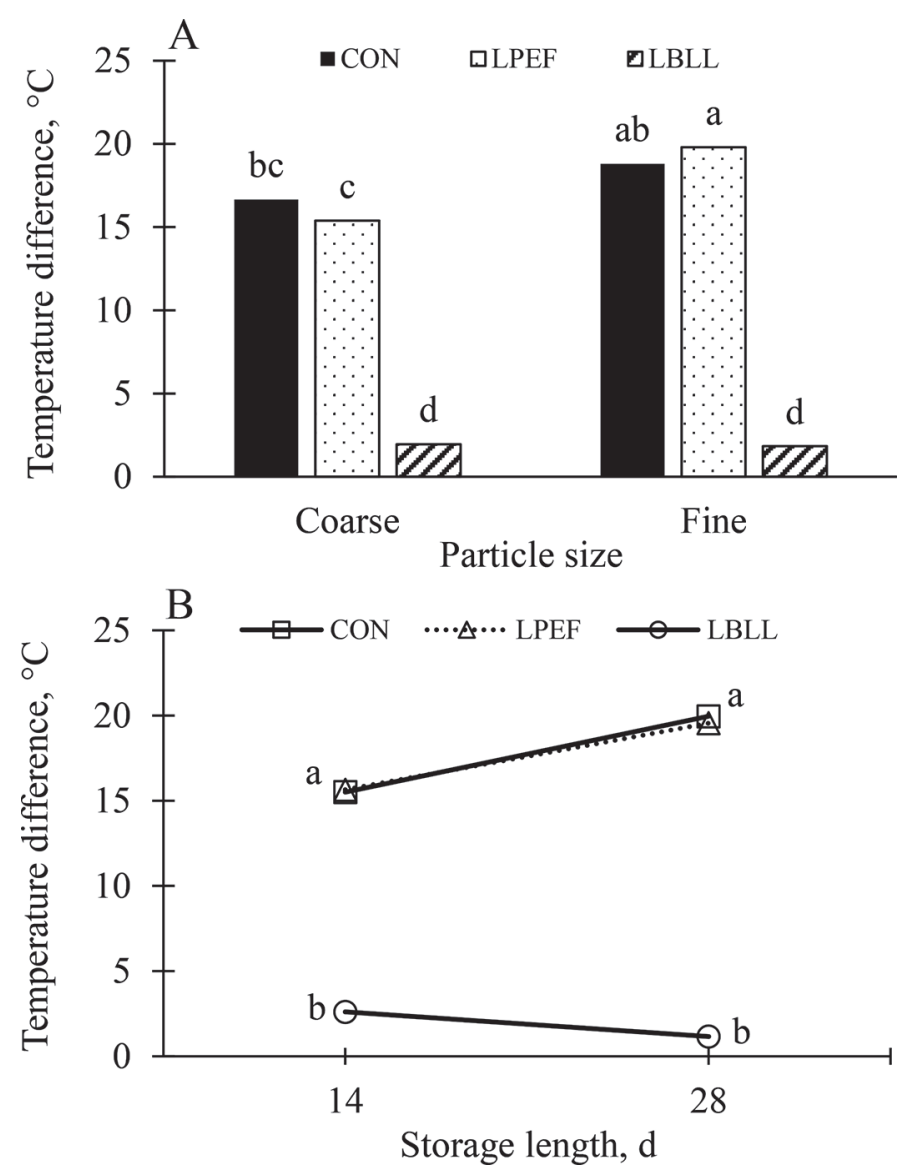

Figure 11. Effects of particle size and microbial inoculation (panel $\mathrm{A} ; P=0.001 ; \mathrm{SEM}=0.53)$ and microbial inoculation and storage length (panel $\mathrm{B} ; P=0.001$; $\mathrm{SEM}=0.57$ ) on the maximum difference between silage temperature and ambient temperature after $10 \mathrm{~d}$ of aerobic exposure. Corn was either coarsely or finely ground before storage. Inoculant treatments were distilled water $(\mathrm{CON})$; Biomax SB (LPEF; Chr. Hansen Animal Health and Nutrition, Milwaukee, WI; application rate of $5 \times 10^{4} \mathrm{cfu} / \mathrm{g}$ of Lactobacillus plantarum $\mathrm{CH} 6072$ and Enterococcus faecium CH212); and SiloSolve FC (LBLL; Chr. Hanson Animal Health and Nutrition; application rate of $7.5 \times 10^{4}$ cfu/g of Lactobacillus buchneri LB1819 and Lactococcus lactis O224). Panel A: means with different letters $(\mathrm{a}-\mathrm{d})$ differed $(P \leq 0.05)$; panel B: means within the same day with different letters $(\mathrm{a}, \mathrm{b})$ differed $(P$ $\leq 0.05)$. gresses in the silo, WSC are converted to organic acids by silage bacteria. Generally, lower WSC concentrations are indicative of a more thorough and complete fermentation. The reduced concentrations of WSC with finely ground LBLL at $28 \mathrm{~d}$ complement Figure 4A, in which the greatest concentrations of total acids were observed in finely ground LBLL. We found no difference in concentrations of starch at $0 \mathrm{~d}$ and $14 \mathrm{~d}$. However, at 28 $\mathrm{d}$, starch concentrations were greater in finely ground LBLL than in finely ground CON. The variability in starch concentrations is difficult to explain. However, changes in WSC concentrations and the method used to determine DM may have influenced this result.

We found a significant effect of particle size on soluble $\mathrm{CP}$ concentrations and ruminal in situ starch degradation (Table 2). Finely ground HMC contained greater concentrations of soluble CP $(P=0.001)$ than coarsely ground HMC. Finely ground corn has increased surface area available for microbial attachment and enzymatic degradation (Huntington, 1997) which may have facilitated the degradation of the hydrophobic protein matrix surrounding starch granules in the silo. Degradation of the starch-protein matrix has been associated with greater soluble CP concentrations in HMC (Hoffman et al., 2011). Baron et al. (1986) found that grinding HMC increased the rate of proteolysis. Ruminal in situ starch degradation also increased dramatically $(P=0.001)$ when HMC was finely ground. This improvement was most likely a result of the combined effects of increased

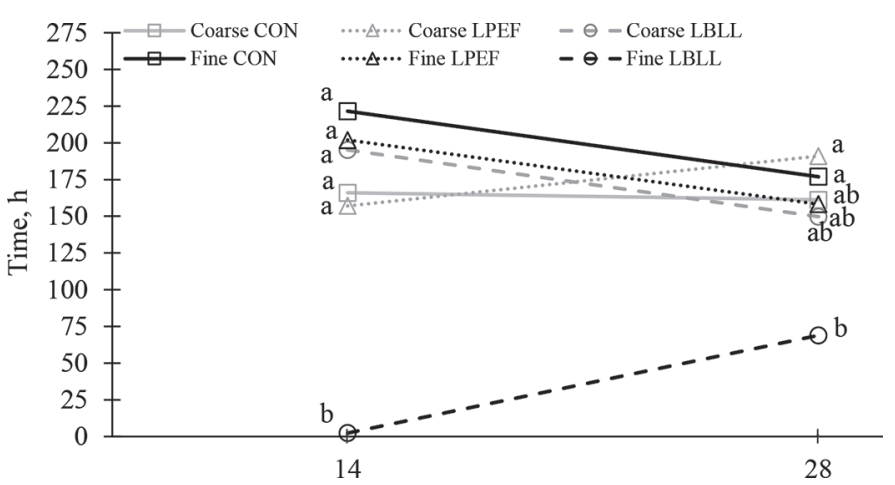

Figure 12. Effect of particle size, microbial inoculation, and storage length on the time to reach the maximum difference between silage temperature and ambient temperature after $10 \mathrm{~d}$ of aerobic exposure. Corn was either coarsely or finely ground before storage. Inoculant treatments were distilled water $(\mathrm{CON})$; Biomax SB (LPEF; Chr. Hansen Animal Health and Nutrition, Milwaukee, WI; application rate of $5 \times 10^{4} \mathrm{cfu} / \mathrm{g}$ of Lactobacillus plantarum $\mathrm{CH} 6072$ and Enterococcus faecium CH212); and SiloSolve FC (LBLL; Chr. Hanson Animal Health and Nutrition; application rate of $7.5 \times 10^{4} \mathrm{cfu} / \mathrm{g}$ of Lactobacillus buchneri LB1819 and Lactococcus lactis O224). Means within the same day with different letters $(\mathrm{a}, \mathrm{b})$ differed $(P \leq 0.05)$. Effects of particle size $(P=0.01)$, microbial inoculation $(P=0.001)$, storage length $(P=0.61)$, and their interaction $(P=0.006)$ were significant; SEM $=23.0$. 
surface area available for ruminal microbial attachment and increased starch availability following the more extensive degradation of the starch-protein matrix in the finely ground HMC. Because the protein matrix is hydrophobic and represents a physicochemical barrier to amylolytic rumen microorganisms, degradation of the matrix can improve ruminal starch digestibility (Hoffman et al., 2011). Ferraretto et al. (2014) reported a positive relationship between soluble $\mathrm{CP}$ concentrations and $7 \mathrm{~h}$ in vitro starch digestibility in HMC.

Soluble CP concentrations and ruminal in situ starch degradation were also influenced by microbial inoculation $(P<0.05$; Table 3$)$. Concentrations of soluble $\mathrm{CP}$ were greater in LBLL than in CON and LPEF. Additionally, ruminal in situ starch degradation was greater with LBLL than with CON and LPEF. McDonald et al. (1991) suggested that lactic acid bacteria are weakly proteolytic, but very little research exists investigating the link between lactic acid bacteria, their proteolytic activity, and their ability to influence starch digestibility in silage. Our data suggests improved proteolysis with LBLL, which likely contributed to increases in ruminal in situ starch degradation. The improvements in ruminal in situ starch degradation with LBLL were most likely unrelated to $\mathrm{pH}$ (Figures $1 \mathrm{~A}$ and $1 \mathrm{C}$ ). Thus, the proteolytic activity of the L. buchneri LB1819 or the identification of other proteolytic microorganisms that may have benefited from the shift in fermentation patterns warrants further investigation. Mean particle size and particle surface area were unaffected by microbial inoculation $(P>0.10$; Table 3$)$.
Concentrations of soluble $\mathrm{CP}$ and ruminal in situ starch degradation were also affected by ensiling $(P=$ 0.001; Table 4). In addition, we found an effect of storage length on soluble $\mathrm{CP}$ concentrations and ruminal in situ starch degradation $(P=0.001$; Table 4$)$. As storage length increased from 14 to $28 \mathrm{~d}$, soluble $\mathrm{CP}$ concentrations and ruminal in situ starch degradation of HMC increased as well. Hoffman et al. (2011) reported increases in soluble CP concentrations in HMC over time up to $240 \mathrm{~d}$. Increases in soluble CP concentrations can be attributed to increased degradation of the starch-protein matrix in the silo. As mentioned previously, degradation of the protein matrix surrounding starch granules directly influences starch digestibility and supports our premise.

The interaction between particle size, microbial inoculation, and storage length for ammonia-N (\% $\mathrm{DM})$ is shown in Figure $15 \mathrm{~A}(P=0.002)$. At $0 \mathrm{~d}$, ammonia- $\mathrm{N}$ concentrations were low, and we found no difference among treatment combinations. Between 0 and $14 \mathrm{~d}$, ammonia- $\mathrm{N}$ concentrations increased across all particle-size and inoculant combinations. At $14 \mathrm{~d}$, concentrations of ammonia- $\mathrm{N}$ were greatest in finely ground LBLL, lowest in coarsely ground CON and LPEF, and intermediate in the other 3 treatment combinations. Ammonia- $\mathrm{N}$ concentrations continued to increase across all treatments from 14 to 28 d. At 28 $\mathrm{d}$, ammonia-N concentrations were greatest in finely ground LBLL and lowest in coarsely ground LPEF and coarsely ground CON. We also found a significant interaction between particle size, microbial inoculation,

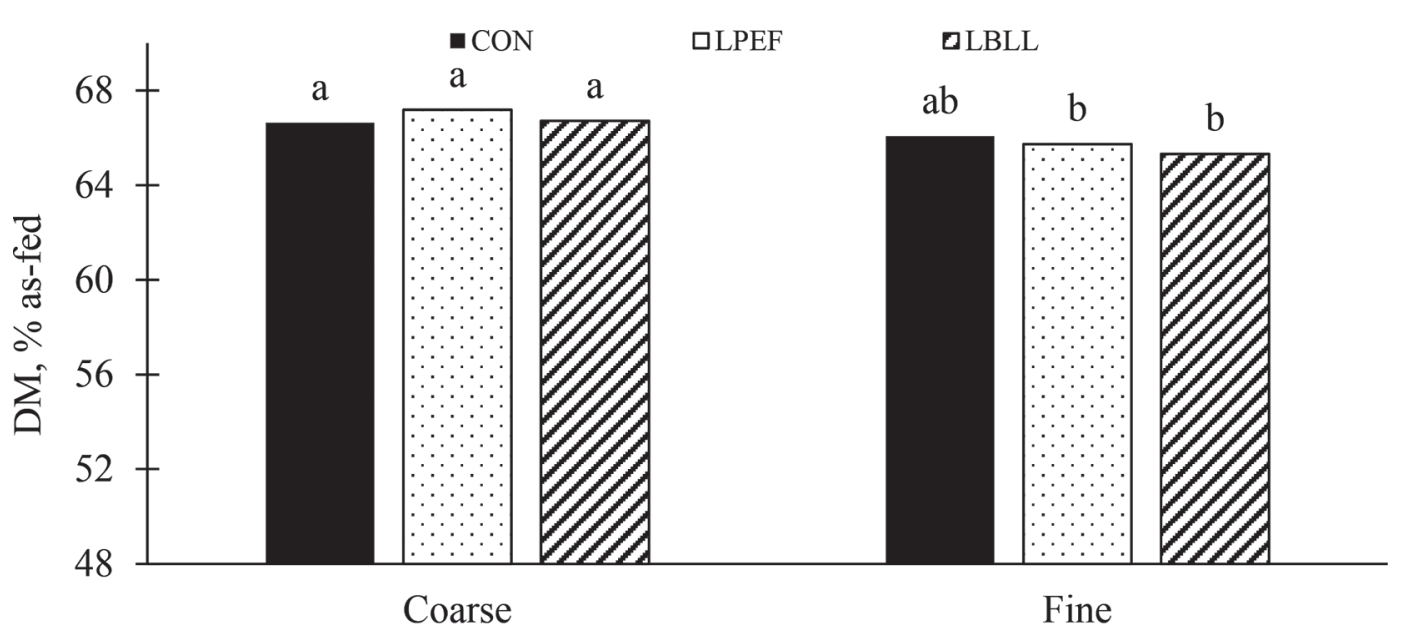

Particle size

Figure 13. Effect of particle size and microbial inoculation $(P=0.02 ; \mathrm{SEM}=0.17)$ on DM concentration of high-moisture corn. Corn was either coarsely or finely ground before storage. Inoculant treatments were distilled water (CON); Biomax SB (LPEF; Chr. Hansen Animal Health and Nutrition, Milwaukee, WI; application rate of $5 \times 10^{4} \mathrm{cfu} / \mathrm{g}$ of Lactobacillus plantarum CH6072 and Enterococcus faecium CH212); and SiloSolve FC (LBLL; Chr. Hanson Animal Health and Nutrition; application rate of $7.5 \times 10^{4} \mathrm{cfu} / \mathrm{g}$ of Lactobacillus buchneri LB1819 and Lactococcus lactis O224). Means with different letters (a, b) differed $(P \leq 0.05)$. 
and storage length for ammonia- $\mathrm{N}(\% \mathrm{~N})$ and, as expected, the results were very similar $(P=0.006$; Figure 15B). Both plant and microbial proteases in the silo are capable of degrading plant proteins to peptides and free amino acids (Muck et al., 2003). The subsequent deamination of amino acids by silage microbes results in an accumulation of ammonia-N (Grum et al., 1991). Similar to what has been discussed previously, ammonia- $\mathrm{N}$ in $\mathrm{HMC}$ is indicative of proteolysis, and ensiling results in increasing concentrations of ammonia- $\mathrm{N}$ as zein proteins are degraded by plant and microbial proteases (Hoffman et al., 2011). Greater ammonia-N in HMC treated with LBLL suggests greater degradation of the starch-protein matrix with this inoculant. The proteolytic activity of LBLL requires further investigation, but the results observed with ammonia-N fit well with what was observed with soluble $\mathrm{CP}$ and ruminal starch degradation (Table 3 ).
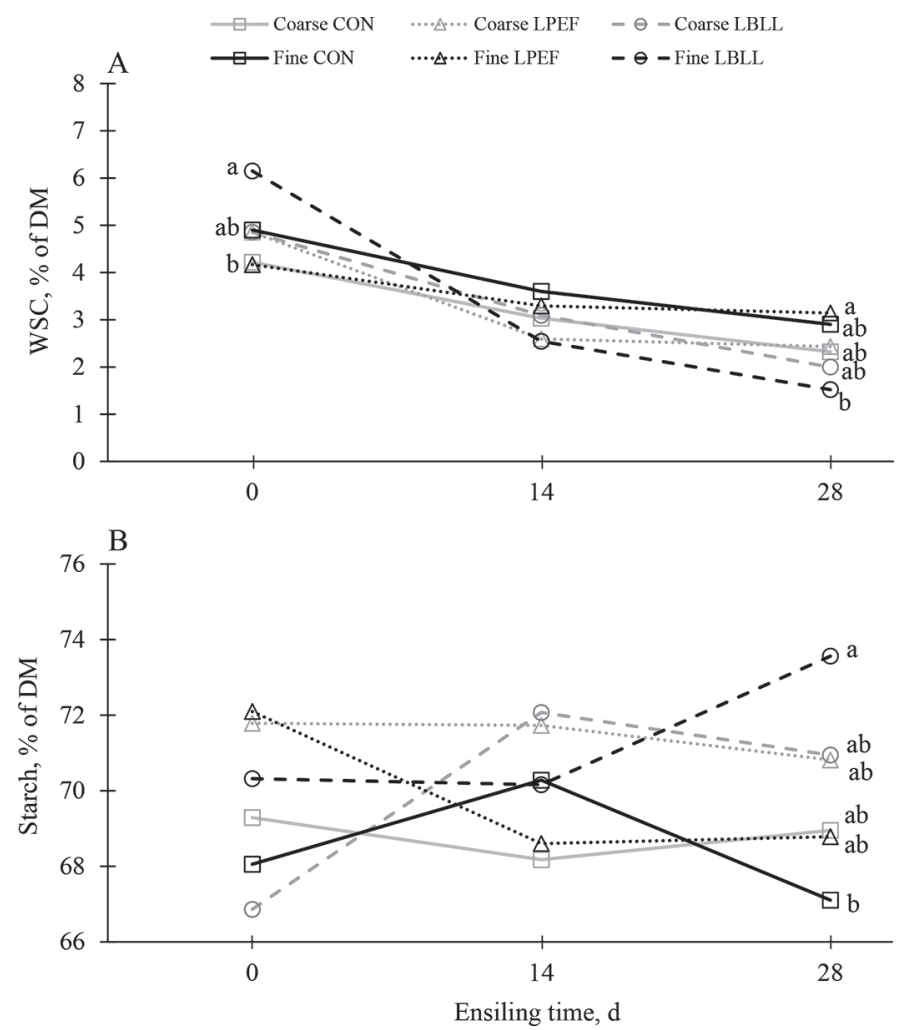

Figure 14. Effects of particle size, microbial inoculation, and storage length on water-soluble carbohydrates (WSC; panel A; $P=0.001$; SEM $=0.28$ ) and starch (panel B; $P=0.04 ; \mathrm{SEM}=1.11$ ) concentrations of high-moisture corn. Corn was either coarsely or finely ground before storage. Inoculant treatments were distilled water (CON); Biomax SB (LPEF; Chr. Hansen Animal Health and Nutrition, Milwaukee, WI; application rate of $5 \times 10^{4} \mathrm{cfu} / \mathrm{g}$ of Lactobacillus plantarum CH6072 and Enterococcus faecium CH212); and SiloSolve FC (LBLL; Chr. Hanson Animal Health and Nutrition; application rate of $7.5 \times 10^{4} \mathrm{cfu} / \mathrm{g}$ of Lactobacillus buchneri LB1819 and Lactococcus lactis O224). Panels A and B: means within the same day with different letters $(\mathrm{a}, \mathrm{b})$ differed $(P \leq 0.05)$.
An interaction between particle size and storage length was observed for mean particle size $(P=0.001$; Figure 16A). As storage length increased from 0 to 14 $\mathrm{d}$, mean particle size decreased for coarsely ground HMC but not for finely ground HMC. Mean particle size was unchanged for both coarsely and finely ground HMC as storage length increased from 14 to $28 \mathrm{~d}$. An interaction between particle size, microbial inoculation, and storage length was observed for particle surface area $(P=0.001$; Figure 16B). As storage length increased from 0 to $14 \mathrm{~d}$, particle surface area increased for coarsely ground HMC but not finely ground HMC. Particle surface area remained unchanged from $14 \mathrm{~d}$ to $28 \mathrm{~d}$ for both finely and coarsely ground HMC. Previous whole-plant corn silage data has suggested that ensiling results in kernel particle size reduction (Ferraretto et al., 2015). A reduction in HMC particle size and an increase in HMC particle surface area with ensiling can

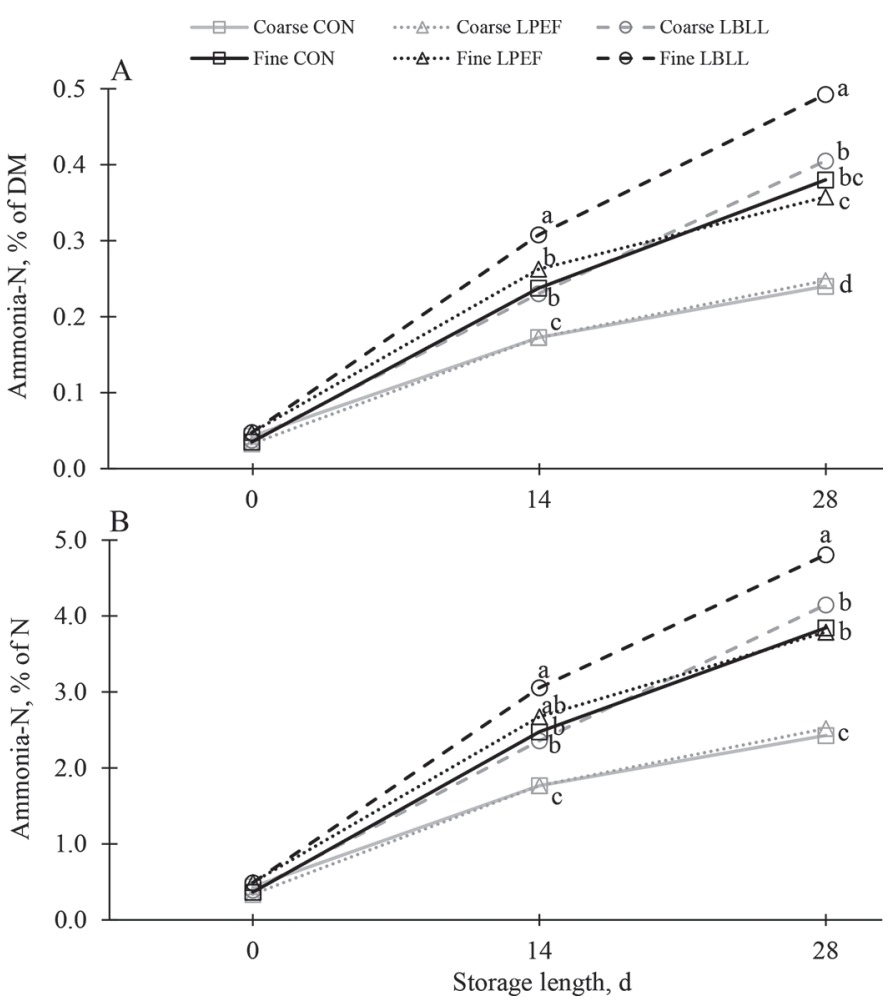

Figure 15. Effects of particle size, microbial inoculation, and storage length on ammonia- $\mathrm{N}$ concentrations of high-moisture corn as a $\%$ of DM (panel A; $P=0.01 ; \mathrm{SEM}=0.01$ ) and as a $\%$ of N (panel B; $P$ $=0.01 ; \mathrm{SEM}=0.09)$. Corn was either coarsely or finely ground before storage. Inoculant treatments were distilled water (CON); Biomax SB (LPEF; Chr. Hansen Animal Health and Nutrition, Milwaukee, WI; application rate of $5 \times 10^{4} \mathrm{cfu} / \mathrm{g}$ of Lactobacillus plantarum $\mathrm{CH} 6072$ and Enterococcus faecium CH212); and SiloSolve FC (LBLL; Chr. Hanson Animal Health and Nutrition; application rate of $7.5 \times 10^{4}$ cfu/g of Lactobacillus buchneri LB1819 and Lactococcus lactis O224). Panels A and B: means within the same day with different letters $($ a-d) differed $(P \leq 0.05)$. 

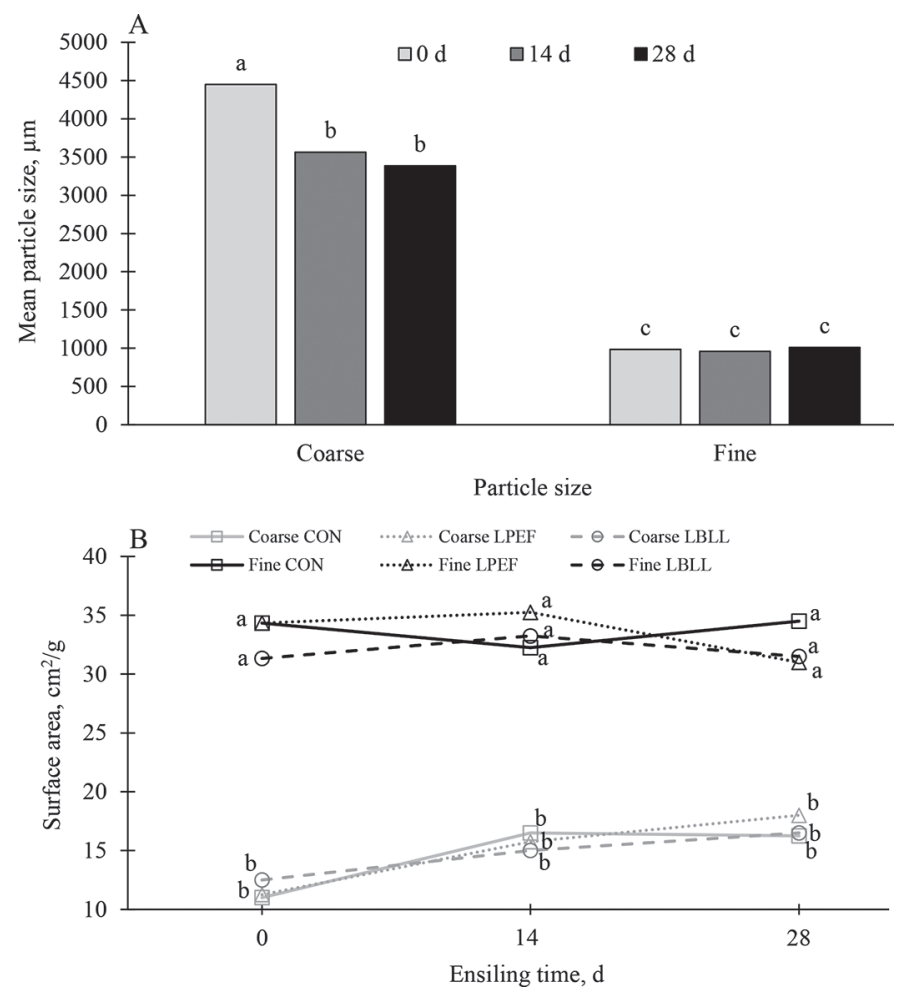

Figure 16. Effect of particle size and storage length on mean particle size (panel A; $P=0.001$, SEM $=69.6$ ) and effect of particle size, microbial inoculation, and storage length on particle surface area (panel B; $P=0.001$, SEM $=0.82$ ) of high-moisture corn. Corn was either coarsely or finely ground before storage. Inoculant treatments were distilled water (CON); Biomax SB (LPEF; Chr. Hansen Animal Health and Nutrition, Milwaukee, WI; application rate of $5 \times 10^{4}$ $\mathrm{cfu} / \mathrm{g}$ of Lactobacillus plantarum $\mathrm{CH} 6072$ and Enterococcus faecium CH212); and SiloSolve FC (LBLL; Chr. Hanson Animal Health and Nutrition; application rate of $7.5 \times 10^{4} \mathrm{cfu} / \mathrm{g}$ of Lactobacillus buchneri LB1819 and Lactococcus lactis O224). Panel A: means with different letters $(\mathrm{a}-\mathrm{c})$ differed $(P \leq 0.05)$; panel $\mathrm{B}$ : means within the same day with different letters $(\mathrm{a}, \overline{\mathrm{b}})$ differed $(P \leq 0.05)$.

improve ruminal starch degradation by increasing the availability of starch granules to microbial degradation in the rumen (Johnson et al., 2002).

\section{CONCLUSIONS}

Microbial inoculation and prolonged ensiling are available methods that could be used by producers to improve the aerobic stability and starch digestibility of HMC, respectively. Unfortunately, prolonged ensiling is not always a possibility, and producers are often challenged with the need to feed HMC with less than $30 \mathrm{~d}$ of fermentation. Results from this study suggest that L. buchneri LB1819 is capable of producing acetic acid in as little as $14 \mathrm{~d}$. Furthermore, L. buchneri LB1819 improved the aerobic stability of HMC after $28 \mathrm{~d}$ of fermentation. In addition, results indicate that L. buchneri LB1819 has the potential to improve the digestibility of starch. Although our soluble CP and ammonia- $\mathrm{N}$ data indicate that the potential mechanism is through the disruption of the zein protein matrix surrounding starch granules, further research is warranted to fully elucidate this. Finally, many farms prefer to feed whole or coarsely ground HMC, which can limit starch digestibility. Data from the present study underscore that fermentation is enhanced and ruminal starch degradation is improved with finely ground HMC.

\section{ACKNOWLEDGMENTS}

Appreciation is extended to Chr. Hansen A/S (Denmark) for partial project funding. We gratefully acknowledge the assistance of the University of Florida Plant Science Research and Education Center (Citra, FL) staff with the experiment.

\section{REFERENCES}

Adesogan, A. T., N. Krueger, M. B. Salawu, D. B. Dead, and C. R. Staples. 2004. The influence of treatment with dual purpose bacterial inoculants or soluble carbohydrates on the fermentation and aerobic stability of bermudagrass. J. Dairy Sci. 87:3407-3416.

AOAC International. 2012. Official Methods of Analysis. 19th ed. AOAC International, Gaithersburg, MD.

ASABE. 2007. Method of determining and expressing fineness of feed materials by sieving. ANSI/ASAE S319.4:646-649. Am. Soc. Agric. Biol. Eng., St. Joseph, MI.

Baker, S., and T. Herrman. 2002. Evaluating Particle Size. MF-2051. Kansas State Univ., Manhattan.

Baron, V. S., K. R. Stevenson, and J. G. Buchanan-Smith. 1986. Proteolysis and fermentation of corn-grain ensiled at several moisture levels and under several simulated storage methods. Can. J. Anim. Sci. 66:451-461.

Borreani, G., E. Tabacco, R. J. Schmidt, B. J. Holmes, and R. E. Muck. 2018. Silage review: Factors affecting dry matter and quality losses in silages. J. Dairy Sci. 101:3952-3979.

da Silva, N. C., C. F. Nascimento, F. A. Nascimento, F. D. de Resende, J. L. P. Daniel, and G. R. Siqueira. 2018. Fermentation and aerobic stability of rehydrated corn grain silage treated with different doses of Lactobacillus buchneri or a combination of Lactobacillus plantarum and Pediococcus acidilactici. J. Dairy Sci. 101:4158-4167.

Daniel, J. L. P., D. Junges, and L. G. Nussio. 2015. A meta-analysis of the effects of length of storage on starch digestibility and aerobic stability of corn silages. Pages 306-307 in Proc. XVII International Silage Conf., Piracicaba, SP, Brazil.

Daniel, J. L. P., O. C. M. Queiroz, K. G. Arriola, R. Daetz, F. Basso, J. J. Romero, and A. T. Adesogan. 2018. Effects of homolactic bacterial inoculant on the performance of lactating dairy cows. J. Dairy Sci. 101:5145-5152.

Driehuis, F., S. J. W. H. Oude Elferink, and S. F. Spoelstra. 1999. Anaerobic lactic acid degradation during ensilage of whole crop maize inoculated with Lactobacillus buchneri inhibit yeast growth and improves aerobic stability. J. Appl. Microbiol. 87:583-594.

Dubois, M., K. A. Gilles, J. K. Hamilton, P. A. Rebers, and F. Smith 1956. Colorimetric method for determination of sugars and related substances. Anal. Chem. 28:350-356.

Ferraretto, L. F., P. M. Crump, and R. D. Shaver. 2013. Effect of cereal grain type and corn grain harvesting and processing methods on intake, digestion and milk production by dairy cows through a meta-analysis. J. Dairy Sci. 96:533-550.

Ferraretto, L. F., G. S. Dias Junior, L. C. de Resende, and R. D. Shaver. 2015. Effect of ensiling on kernel processing score in whole- 
plant corn silage harvested with varied processors and settings. J. Dairy Sci. 98(Suppl. 2):692. (Abstr.)

Ferraretto, L. F., K. Taysom, D. M. Taysom, R. D. Shaver, and P. C. Hoffman. 2014. Relationships between dry matter content, ensiling, ammonia-nitrogen, and ruminal in vitro starch digestibility in high-moisture corn samples. J. Dairy Sci. 97:3221-3227.

Firkins, J. L., M. L. Eastridge, N. R. St-Pierre, and S. M. Noftsger. 2001. Effects of grain variability and processing on starch utilization by lactating dairy cattle. J. Anim. Sci. 79(Suppl. E):E218E238.

Grum, D. E., W. L. Shockey, and W. P. Weiss. 1991. Electrophoretic examination of alfalfa silage proteins. J. Dairy Sci. 74:146-154.

Hall, M. B. 2015. Determination of dietary starch in animal feeds and pet food by an enzymatic-colorimetric method: Collaborative study. J. AOAC Int. 98:397-409.

Hoffman, P. C., N. M. Esser, R. D. Shaver, W. K. Coblentz, M. P. Scott, and A. L. Bodnar. 2011. Influence of ensiling time and inoculation on alteration of the starch-protein matrix in high-moisture corn. J. Dairy Sci. 94:2465-2474.

Hoffman, P. C., and S. M. Ocker. 1997. Quantification of milk yield losses associated with feeding aerobically unstable high moisture corn. J. Dairy Sci. 80(Suppl. 1):234 (Abstr.).

Holmes, B. J. 2006. Density in silage storage. Pages 214-238 in Silage for Dairy Farms: Growing, Harvesting, Storing, and Feeding Conf. Proc. (NRAES-181), Harrisburg, PA. Natural Resource, Agriculture, and Engineering Service, Ithaca, NY.

Huntington, G. B. 1997. Starch utilization by ruminants: From basics to the bunk. J. Anim. Sci. 75:852-867.

Johnson, L. M., J. H. Harrison, D. Davidson, J. L. Robutti, M. Swift, W. C. Mahanna, and K. Shinners. 2002. Corn silage management I: Effects of hybrid, maturity, and mechanical processing on chemical and physical characteristics. J. Dairy Sci. 85:833-853.

Junges, D., G. Morais, M. H. F. Spoto, P. S. Santos, A. T. Adesogan, L. G. Nussio, and J. L. P. Daniel. 2017. Short communication: Influence of various proteolytic sources during fermentation of reconstituted corn grain silages. J. Dairy Sci. 100:9048-9051.

Kleinschmit, D. H., and L. Kung Jr.. 2006. The effects of Lactobacillus buchneri 40788 and Pediococcus pentosaceus R1094 on the fermentation of corn silage. J. Dairy Sci. 89:3999-4004.

Kotarski, S. F., R. D. Waniska, and K. K. Thurn. 1992. Starch hydrolysis by the ruminal microflora. J. Nutr. 122:178-190.

Krishnamoorthy, U., T. V. Muscato, C. J. Sniffen, and P. J. Van Soest. 1982. Borate phosphate procedure as detailed in nitrogen fractions in selected feedstuffs. J. Dairy Sci. 65:217-225.

Kung, L. Jr., R. J. Schmidt, T. E. Ebling, and W. Hu. 2007. The effect of Lactobacillus buchneri 40788 on the fermentation and aerobic stability of ground and whole high-moisture corn. J. Dairy Sci. 90:2309-2314.

Kung, L. Jr., R. D. Shaver, R. J. Grant, and R. J. Schmidt. 2018. Silage review: Interpretation of chemical, microbial, and organoleptic components of silages. J. Dairy Sci. 101:4020-4033.

McAllister, T. A., R. C. Phillippe, L. M. Rode, and K. J. Cheng. 1993. Effect of the protein matrix on the digestion of cereal grains by ruminal microorganisms. J. Anim. Sci. 71:205-212.
McDonald, P., N. Henderson, and S. Heron. 1991. The Biochemistry of Silage. 2nd ed. Chalcombe Publications, Marlow, United Kingdom.

Moon, N. J. 1983. Inhibition of the growth of acid tolerant yeasts by acetate, lactate, and propionate and their synergistic mixtures. J. Appl. Bacteriol. 55:453-460.

Muck, R. E. 1988. Factors affecting silage quality and their implications for management. J. Dairy Sci. 71:2992-3002.

Muck, R. E. 2010. Silage microbiology and its control through additives. Rev. Bras. Zootec. 39:183-191. (Special Issue).

Muck, R. E., and L. Kung Jr. 1997. Effects of silage additives ensiling. Pages 187-199 in Proc. Silage: Field to Feedbunk (NRAES-99), Hershey, PA. Natural Resource, Agriculture, and Engineering Service, Ithaca, NY.

Muck, R. E., L. E. Moser, and R. E. Pitt. 2003. Postharvest factors affecting enisling. Pages 251-304 in Silage Science and Technology. D. R. Buxton, R. E. Muck, and J. H Harrison, ed. American Society of Agronomy, Madison, WI.

NFTA (National Forage Testing Association). 1993. Forage Analysis Procedures. Method 2.2.2.5. Natl. Forage Test. Assoc., Lincoln, NE.

Oude Elferink, S. J. W. H., J. Krooneman, J. C. Gottschal, S. F. Spoelstra, F. Faber, and F. Driehuis. 2001. Anaerobic conversion of lactic acid to acetic acid and 1,2-propanediol by Lactobacillus buchneri. Appl. Environ. Microbiol. 67:125-132.

Pahlow, G., R. E. Muck, F. Driehuis, S. J. W. H. Oude Elferink, and S. F. Spoelstra. 2003. Microbiology of ensiling. Pages 31-93 in Silage Science and Technology. D. R. Buxton, R. E. Muck, and J. H. Harrison, ed. American Society of Agronomy, Madison, WI.

Schmidt, R. J., and L. Kung Jr.. 2010. The effects of Lactobacillus buchneri with or without a homolactic bacterium on the fermentation and aerobic stability of corn silages made at different locations. J. Dairy Sci. 93:1616-1624.

Simpson, D. J. 2001. Proteolytic degradation of cereal-prolaminsThe problem with proline. Plant Sci. 161:825-838.

St. Germain, G., and R. Summerbell. 2010. Identifying Fungi: A Clinical Laboratory Handbook. 2nd ed. Star Pub. Co. Inc.

Tabacco, E., F. Righi, A. Quarantelli, and G. Borreani. 2011. Dry matter and nutritional losses during aerobic deterioration of corn and sorghum silages as influenced by different lactic acid bacteria inocula. J. Dairy Sci. 94:1409-1419.

Taylor, C. C., and L. Kung Jr.. 2002. The effect of Lactobacillus buchneri 40788 on the fermentation and aerobic stability of high moisture corn in laboratory silos. J. Dairy Sci. 85:1526-1532.

Woolford, M. K. 1984. The Silage Fermentation. 2nd ed. Marcel Dekker, New York, NY.

\section{ORCIDS}

F. Casale $\odot$ https://orcid.org/0000-0003-3712-5440

L. F. Ferraretto $\odot$ https://orcid.org/0000-0003-4711-8332 


\section{APPENDIX}

Table A1. Particle size characterization (mean \pm SD) of unfermented high-moisture corn

\begin{tabular}{lcc}
\hline & \multicolumn{2}{c}{ Particle size } \\
\cline { 2 - 3 } & $\begin{array}{c}\text { Coarsely } \\
\text { ground }\end{array}$ & $\begin{array}{c}\text { Finely } \\
\text { ground }\end{array}$ \\
\hline Item & & \\
4.75 & & \\
3.35 & $66.1 \pm 19.3$ & $1.5 \pm 0.86$ \\
2.36 & $15.5 \pm 4.7$ & $3.9 \pm 0.96$ \\
1.70 & $8.9 \pm 2.9$ & $8.9 \pm 1.2$ \\
1.18 & $4.1 \pm 1.5$ & $11.7 \pm 1.6$ \\
0.60 & $2.4 \pm 1.1$ & $14.4 \pm 2.8$ \\
0.30 & $2.1 \pm 1.2$ & $21.7 \pm 3.6$ \\
0.15 & $0.7 \pm 0.41$ & $17.7 \pm 2.7$ \\
Pan & $0.2 \pm 0.08$ & $9.2 \pm 5.1$ \\
Geometric mean particle size, $\mu \mathrm{m}$ & $0.0 \pm 0.04$ & $1.0 \pm 0.87$ \\
Particle surface area, $\mathrm{cm}^{2} / \mathrm{g}$ & $11.6 \pm 1.2$ & $33.3 \pm 2.5$ \\
\hline
\end{tabular}

${ }^{1}$ Values are expressed as a percentage of particles retained on each sieve.

Table A2. Identity of detected molds found in high-moisture corn silage at d 0

\begin{tabular}{|c|c|c|c|c|c|}
\hline \multirow[b]{2}{*}{ Particle size } & \multirow{2}{*}{$\begin{array}{l}\text { Inoculation } \\
\text { treatment }^{1}\end{array}$} & \multicolumn{3}{|c|}{ Mold, $\%$ of total molds } & \multirow[b]{2}{*}{ Other } \\
\hline & & Monascus spp. & Penicillium spp. & Aspergillus spp. & \\
\hline \multirow[t]{2}{*}{ Coarsely ground } & $\mathrm{CON}$ & 100 & 0 & 0 & 0 \\
\hline & LBLL & 87.5 & 0 & 12.5 & 0 \\
\hline \multirow[t]{2}{*}{ Finely ground } & $\mathrm{CON}$ & 100 & 0 & 0 & 0 \\
\hline & LPEF & 100 & 0 & 0 & 0 \\
\hline
\end{tabular}

${ }^{1}$ Treatments were distilled water (CON); Biomax SB (LPEF; Chr. Hansen Animal Health and Nutrition, Milwaukee, WI; application rate of 5 $\times 10^{4} \mathrm{cfu} / \mathrm{g}$ of Lactobacillus plantarum CH6072 and Enterococcus faecium CH212); and SiloSolve FC (LBLL; Chr. Hanson Animal Health and Nutrition; application rate of $7.5 \times 10^{4} \mathrm{cfu} / \mathrm{g}$ of Lactobacillus buchneri LB1819 and Lactococcus lactis O224). Inoculation rates were based on $\mathrm{cfu} / \mathrm{g}$ of fresh forage. 